\title{
EXCHANGE RATE MODELLING IN THE DEVELOPMENT COMMUNITY USING THE ARDL COINTEGRATION APPROACH: THE CASE OF EMERGING MARKETS
}

\author{
Abdulkader Aljandali *, Christos Kallandranis \\ * Corresponding author, Faculty of Business and Law, School of Economics, Finance and Law, Anglia Ruskin University, the UK \\ Contact details: Anglia Ruskin University, Chelmsford, CM1 1SQ, the UK \\ ** Department of Accounting, Finance and Economics, Regent's University London, the UK
}

\section{OPEN ACCESS}

How to cite this paper: Aljandali, A., \& Kallandranis, C. (2020). Exchange rate modelling in the development community using the ARDL cointegration approach: The case of emerging markets. Risk Governance and Control: Financial Markets \& Institutions, 10(2), 53-70. http://doi.org/10.22495/rgcvl0i2p5

Copyright $\odot 2020$ The Authors

This work is licensed under a Creative Commons Attribution 4.0 International License (CC BY 4.0).

https://creativecommons.org/licenses/ by/4.0/

ISSN Online: 2077-4303

ISSN Print: 2077-429X

Received: 23.05 .2020 Accepted: 03.07.2020

JEL Classification: C53, F31, F36 DOI: $10.22495 / \mathrm{rgcv} 10 \mathrm{i} 2 \mathrm{p} 5$

\begin{abstract}
Despite rising interest in African economies, there is little prior research on the determinants of exchange rate movements in the region. This paper examines the monthly exchange rates of the country members of the Southern African Development Community (SADC) from 1990 to 2010 inclusive. Long-run equilibrium exchange rate models are established, exchange rate determinants are identified, and ex-post forecasts are generated for a period of 18 months (Sekantsi, 2011). The autoregressive distributed lag (ARDL) cointegration model is used in this paper, given its statistical advantages over commonly, applied cointegration techniques. Findings show that the ARDL method generates accurate forecasts for eight out of 11 sampled exchange rates. In keeping with earlier literature (e.g., Redda \& Muzindusti, 2017; Zerihun \& Breitenbach, 2017; etc.), findings suggest that the chances of SADC member countries fulfilling the requirements of a currency union are quite low. This paper marks one of the first attempts in the literature to forecast exchange rates in SADC using the ARDL approach (Pesaran \& Shin, 1995). The results would be of interest to policy-makers, researchers and investors.
\end{abstract}

Keywords: African Economies, Exchange Rates, Regional Integration, Cointegration

Authors' individual contribution: Conceptualization - A.A. and C.K.; Methodology - A.A.; Writing - Original Draft - A.A. and C.K.; Investigation - C.K.; Resources - A.A.; Supervision - C.K.; Project Administration - A.A.; Writing - Review \& Editing - C.K.

Declaration of conflicting interests: The Authors declare that there is no conflict of interest.

\section{INTRODUCTION}

Africa has a long tradition of regional cooperation, its trade and monetary integration schemes being the oldest in the developing world. Since the beginning of the 1990s, African regional cooperation has been revitalised due to two main developments; firstly, the abolition of the apartheid regime in South Africa and secondly, the transformation of the organisation of African unity into the African Union (AU). The latter launched the New Partnership for Africa's Development (NEPAD) initiative in 2001 which considers regional economic communities as building blocks for pan-African integration and has among its aims a common African currency. The anticipated process leading to African Monetary Union comprises various stages, including macroeconomic convergence, monetary integration, 
and monetary union at the regional level, following which, the regional monetary unions would come together to form a full African Monetary Union, with a single currency and central bank by 2021 (e.g., Belle, 2010; Zerihun \& Breitenbach, 2017; Redda, Muzindusti, \& Grobler, 2017; etc.). Support for the African Monetary Union as a long-term policy initiative is based on a perception that it is both feasible and beneficial to countries engaged in regional integration. The $\mathrm{AU}$ put an end to an era that where coordination was understood to be political rather than economical. According to Peters (2010), one of the strengths of the AU is that the signatories were aware of the fact that economic integration was not a choice anymore but a necessary route for the development of the continent. In fact, the $\mathrm{AU}$ has agreed in principle, to implement monetary union and a single currency in Africa based upon the prior formation of regional monetary unions, including one in the SADC region (Jeffries, 2007; Redda et al., 2017).

Regional integration appealed as a concept to many economists, politicians and business people as it promised to increase the wealth and well-being not just of one but a number of countries at a rate greater than the sums of the separate development of the economies of the participating countries (Peters, 2010). SADC has been labelled by experts as currently the most successful and promising attempt at regional integration in Africa (ECA, 2008; Mair \& Christian, 2001; Brandt, Gsanger, Otzen, \& Qualmann, 2000). SADC started in 1992 with ten country members that share a vision of a common future with a regional community that will ensure better standards of living and quality of life, freedom and social justice and peace and security for its people. This shared vision is anchored in the common values and principles and the historical and cultural affinities that exist across the region.

This paper examines exchange rate fluctuations in the SADC region from 1990 to 2010 . Forecasts are generated using the ARDL cointegration approach whilst model performance is measured using the mean absolute percentage error (MAPE) given that the latter possesses the advantage of unit-free measure for model adequacy (Lewis, 1982). Forecasts and determinants of exchange rates in 12 SADC countries are established via cointegration modelling. Applications of cointegration methods to exchange rates fall into two classes. The first examines whether systems of exchange rates are cointegrated. In respect of SADC countries, the purpose is to assess the level of financial integration of the member states by empirically examining co-movements between their individual exchange rates. One of the benefits of financial integration is that it enhances financial stability because openness to international competition requires that countries conform to international standards of reporting and financial regulation (Motelle \& Biekpe, 2015). The second class involves applying cointegration in the search for long-run equilibrium between each individual SADC exchange rate and potential macroeconomic determinants. The latter type of applications will thus generate explanatory factors that underpin any degree of financial integration that exists in the SADC region. This paper consequently contributes to the second class of cointegration models. The next section reviews applications of long-run equilibrium modelling of exchange rates, but unlike the present study, such research often uses a relatively small set of potential explanatory factors. A third section outlines the terminology and mechanics of ARDL modelling within the context of the statistical assumptions that underpin a successful model. A fourth section provides the sources used for the raw data applied in this research and defines the potential explanatory variables that are used in the ARDL models of exchange rate behaviour. A fifth section presents the results of the ARDL modelling process and there is a final section for conclusion.

\section{REVIEW OF THE LITERATURE AND COINTEGRATION APPROACH}

In Africa, Adeniyi, Omisakin, and Oyinlola (2011) established that a cointegration relationship exists between trade balance, real effective exchange rate, and domestic income in Ghana, Gambia, Nigeria, and Sierra Leone. Adebiyi (2007) investigated the impact of foreign exchange intervention by the Central Bank of Nigeria in the exchange market using an ARDL modelling approach. The variables used include cumulative net foreign assets, cumulative aid, broad money supply, and growth domestic product. Quarterly time series data spanning from 1986 to 2003 were used and the overall finding was that there is a relationship between foreign exchange intervention in Nigeria and the cumulative aid, which constitute part of foreign exchange inflows and net foreign assets. Auwal (2010) argued that there is evidence of a long-run relationship between demand for foreign exchange and the marginal rate of the Nigerian naira. Sekantsi (2011) empirically examined the impact of real exchange rate volatility on trade in the context of South Africa's exports to the U.S. for South Africa's floating period January 1995February 2007. After establishing the existence of cointegration among the variables involved in two-country export model, they estimated long-run coefficients by means of ARDL bounds testing procedure proposed by Pesaran, Shin, and Smith (2001). He concluded that stable and competitive exchange rate and sound macroeconomic fundamentals were required in order to improve international competitiveness and greater penetration of South African exports to international markets. In this line, Zerihun and Breitenbach (2017), confirm the existence of cointegration and stationarity in real exchange rate series among 11 SADC member countries. This result can be thought as an indication of possible further monetary integration. In a recent paper Asongu, Folarin, and Biekpe (2019) examine the stability of demand for money within the context of a common currency are for SADC countries. They provide evidence of such a development in the longterm if synchronization of certain macroeconomic criteria is enhanced. Finally, Breitenbach, Zerihun, and Kasongo (2020), for a panel of inflationtargeting countries in Africa, present the existence of cointegration in the country-by-country cases and weak evidence of cointegration between real exchange rate and real interest rate differentials. From a policy point of view this suggests that real interest rate differentials are not a good predictor of real exchange rates in inflation-targeting countries.

All in all, the vast majority of the literature focuses on cointegration tests. Indeed, cointegration 
was introduced into the financial literature by Granger (1981) and elaborated further by Engle and Granger (1987), Engle and Yoo (1987), Johansen (1988) and Pesaran and Shin (1996, 1999) amongst others. Cointegration studies generally seek to establish a relationship between a dependent variable and a set of independent, explanatory variables when there is the possibility that non-stationary variables are involved. The method avoids the well-known spurious regression problem. Engle and Granger (1987) demonstrated that any cointegrated relationship has what is called an error correction form which permits a relationship between a dependent variable and significant explanatory variables that can diverge in the short run, yet which will converge in the long run. An error correction form thereby integrates the short-run dynamics with long-run equilibrium without losing long-run information.

The ARDL form of cointegration was a later development introduced by Pesaran and Shin (1995). Just as with other forms of cointegration, ARDL models also involve estimating an error correction form of the relationship between a dependent variable and its determinants. Most studies that use ARDL models for exchange rate determination in developing countries are quite recent. Emerging world countries adopted fixed exchange rate regimes and macroeconomic variables did not respond to the traditional forces of the market but were rather manipulated by respective central banks. This trend lost momentum during the last two decades as researchers examined various aspects of the foreign exchange markets using the ARDL method. A number of studies focus on the BRIC group, Gulf countries and Southeast Asia (Bahmani-Oskooee \& Rehman, 2005; Akinlo, 2006; Samreth, 2008; Long \& Samreth, 2008; Baharumshah, Mohd, \& Masih, 2009; Achsani, 2010; Sbeiti \& Al Shammari, 2010; AbuDalu \& Almasaied, 2011) as well as other developing areas (Shahbaz, Awan, \& Ahmad, 2011; Lin, 2012; Odhiambo, 2014). More recent studies examine causality between exchange rates and stock exchange movements (Türsoy, 2017), exchange rates, and inflation (Apeh, Auwal, \& Obinna, 2019) and exchange rates and FDI (Dahir, Mahat, Bany-Ariffin, \& Ab Razak, 2017).

\section{METHODOLOGY}

\subsection{The empirical model}

The simplest ARDL model would attempt to explain one variable based on its past values and would also include current or lagged values of a second variable. Since lagged effects are possible, we say that the dynamic effects of a change in $X_{t}$ upon $Y_{t}$ can be modeled and explained as follows:

$$
Y_{t}=\mu+\vartheta Y_{t-1}+\varphi_{0} X_{t}+\varphi_{1} X_{t-1}+e_{t}
$$

where, $Y_{t}$ is the observed value of the $Y$ series at time $t ; Y_{t-1}$ is the observed value of the $Y$ series at time $t-1 ; X_{t}$ is the observed value of the $X$ series at time $t ; X_{t-1}$ is the observed value of the $X$ series at time $t-1 ; e_{t}$ is an error term and $\mu, \vartheta, \varphi_{0}, \varphi_{1}$ are parameters of the model to be estimated. If we subtract $Y_{t-1}$ from both sides of equation (1) and use the first difference operator $\Delta$, we obtain:

$$
\Delta Y_{t}=\mu+\vartheta Y_{t-1}-Y_{t-1}+\varphi_{0} X_{t}+\varphi_{1} X_{t-1}+e_{t}
$$

which with a little algebraic manipulation can be re-written as:

$$
\Delta Y_{t}=\varphi_{0} \Delta X_{t}-(1-\vartheta)\left[Y_{t-1}-\alpha-\beta X_{t-1}\right]+e_{t}
$$

where $\alpha=\frac{\mu}{1-\vartheta}$ and $\beta=\frac{\varphi_{0}+\varphi_{1}}{1-\vartheta}$. Equation (2) is referred to as the error correction form of the ARDL model. $\Delta X_{t}=X_{t}-X_{t-1}$ denotes changes in an explanatory variable in the short term. For example, if we assume that current exchange rates $\left(Y_{t}\right)$ are affected by changes in a trade variable $\left(X_{t}\right)$, then the difference in the level of trade between the current and previous time periods is denoted as $\Delta X_{t}$ and an increase of one unit in $X_{t}$ will have an immediate impact on $Y_{t}$ of $\varphi_{0}$ units from equation (2). In other words, $\Delta X_{t}$ measures the short-term change in the exchange rate due to a change in the explanatory variable (in this example, level of trade). The term in square brackets in equation (2) represents the long-run equilibrium position. The error correction (or adjustment) parameter is denoted by $(1-\vartheta)$ above, which should be significantly different from zero to validate the long-run relationship $\left[Y_{t-1}-\alpha-\beta X_{t-1}\right]$. Importantly, a small error correction term indicates that exchange rates will return relatively quickly to the long-run equilibrium position while a large value indicates that a shock to the system may have a long-lasting effect on exchange rate values. Ordinary least squares can be applied to equation (2) in order to establish the parameter estimates. Equation (2) is said to be a reparameterisation of equation (1) but other reparameterisations are possible. Consider a more general ARDL model in which the $Y_{t}$ variable is lagged by p-time periods. Furthermore, assume that there are $k X_{t}$ variables which for simplicity are all lagged by q-time periods. The Microfit version 5.0 software package (Pesaran \& Pesaran, 2009) uses the following reparameterisation to establish an error correction form:

$$
\begin{gathered}
\Delta Y_{t}=\pi+\sum_{i=1}^{q-1} \beta_{i} \Delta Y_{t-i}+\sum_{i=1}^{q-1} \gamma_{i} \Delta X_{1, t-i}+\sum_{i=1}^{q-1} \tau_{i} \Delta X_{2, t-i}+\cdots+\sum_{i=1}^{q-1} \theta_{i} \Delta X_{k, t-i}+ \\
+\left[\delta_{1} Y_{t-1}+\delta_{2} X_{1, t-1}+\delta_{3} X_{2, t-1} \ldots+\delta_{k} X_{k, t-1}\right]+e_{t}
\end{gathered}
$$

Where, $\sum_{i=1}^{q-1} \beta_{i} \Delta Y_{t-i}$ indicates past changes in the dependent variable (exchange rates); $\sum_{i=1}^{q-1} \gamma_{i} \Delta X_{1, t-i}$ indicates past changes in the first explanatory variable; $\sum_{i=1}^{q-1} \tau_{i} \Delta X_{2, t-i}$ indicates past changes in the second explanatory variable; $\sum_{i=1}^{q-1} \theta_{i} \Delta X_{k, t-i}$ indicates past changes in the $k$-th explanatory variable and $\left[\delta_{1} Y_{t-1}+\delta_{2} X_{1, t-1}+\delta_{3} X_{2, t-1}+\right.$ $\left.\cdots+\delta_{k} X_{k, t-1}\right]$ is the long-run equilibrium part of the model. 
Microfit selects the appropriate lag order for all of the study variables in equation (3) via a choice between statistical measures called the Akaike Information Criterion (AIC), the Schwartz Bayesian Criterion (SBC), or the Hannan-Quinn Criterion (which is numerically intermediate between the AIC and SBC). The SBC leans towards parsimony (the least number of estimated parameters in the formulation of the associated original equation (1)) and the AIC selects the least parsimonious model. Nevertheless, both criteria lead to point estimates of the long-run parameters that are numerically similar. This study used the SBC. The existence of a long-run relationship between the levels of the variables at hand is tested via an F-statistic that examines $H_{0}: \delta_{1}=\delta_{2}=\cdots=\delta_{k}=0$ in respect of equation (3) - i.e., the non-existence of a long-run relationship. Significance levels associated with these F-statistics are non-standard and are computed by simulation dependent upon the number of explanatory variables, $k$ (Pesaran et al., 2001). Assessments of the significance of the individual terms in the short- and long-run components of equation (3) are carried out via t-statistics.

\subsection{Parameter stability tests}

Just as with all regression-based techniques, there are statistical assumptions made about the ARDL model's residuals. They should exhibit no serial (or temporal) autocorrelation, should be homoskedastic (i.e., exhibit constant variance over time) and be normally distributed. Each of these three nulls can be formally tested via chi-squared statistics. The CUSUM (cumulative sum) and the CUSUMSQ (cumulative sum of squares) tests of Brown, Durbin, and Evans (1975) are widely used to assess model stability (Cameron, 2005). Both are graphical procedures dependent on the values of the standardized recursive residuals obtained from the ARDL model. The CUSUM of standardized recursive residuals is plotted over time. If the recursive residuals are independently and randomly distributed with zero means, they should not exhibit a tendency to cumulatively increase or decrease over time. The key point is whether departures from zero fall outside a pair of (typically) 5\% significance lines, the distance between which increases with the number of residuals. If the CUSUM strays outside these significance lines at a particular point in time, then there is evidence that the residual variance is not constant which implies that model parameters too are not constant during the sample period. This would infer there is a structural break in the data. The CUSUMSQ involves the cumulative sum of the squared recursive residuals and has an expected value that ranges from zero to one and is again plotted over time. The significance of departures of CUSUMSQ from its expected value is again assessed according to whether or not its value crosses a pair of significance lines. Movement outside these lines is indicative of non-constant residual variance and consequently model parameter instability. If CUSUMSQ lies within the significance lines, it suggests that the residual variance is stable.

\section{DATA SOURCES AND A DESCRIPTION OF EXPLANATORY VARIABLES USED}

Monthly data relating to 12 SADC countries for the period from 1990 to 2010 inclusive. The historical period selection was based on data availability for the main variable of interest, i.e., the exchange rates, as well as determinants used for the ARDL modeling process. Exchange rates, expressed in terms of special drawing rights (SDR), as well as other variables, were collected from the IMF international financial statistics database. Exchange rate fluctuations have been largely explained by macroeconomic variables (Yin \& Li, 2014) and a recent strand of the literature, the so-called new open economy macroeconomics, argues that non-monetary factors have gained importance in explaining the real exchange rate variability (Zakaria \& Ghauri, 2011). That is, variables like imports and exports should be taken into account when explaining real exchange rate variability in line with the traditional theory of exchange rate determination which stipulates that a healthy exchange rate is supported by rising exports and low imports.

Researchers have also looked at the relationship between exchange rates and trade balance and there are studies that argue that there is statistical evidence connecting the two (Himarios, 1989; Bahmani-Oskooee, 2001; Duasa, 2007). The traditional view of exchange rate determination promotes the idea that exchange rates will adjust to changes in the trade balance of the country under study regardless of changes in monetary aggregates (Hallwood \& MacDonald, 2000). In the same context, the World Bank (2002) emphasised the advantages of trade openness for developing economies. Furthermore, trade openness of an economy is a crucial characteristic in assessing the feasibility of a monetary union and the adoption of a common currency (Redda et al., 2017). Moreover, financial integration facilitates transfer of technology and know-how that improves efficiency and stability in the domestic financial sector (Motelle \& Biekpe, 2015). A widely used definition of a trade openness index is applied in this paper, namely that trade openness is the ratio of a country's total trade (imports plus exports) to that country's gross domestic product (Yanikkaya, 2003). A complementary view states that the exchange rate is used as a tool to bring down inflation. In general, a country with a consistently lower inflation rate exhibits a rising currency value, as its purchasing power increases relative to other currencies. Some economists state that one of the costs of inflation targeting is precisely the higher volatility of exchange rate which can entail negative effects of particular relevance to emerging economies given their greater financial and real vulnerabilities (e.g., Cavoli, 2008; Iyke \& Odhiambo, 2017; etc.). Changes in the gross domestic product were also stated as a factor that impacts exchange rate fluctuations. Adeniyi et al. (2011) established that a relationship exists between the effective exchange rate and domestic income in various emerging markets. Additionally, Poon (2010) found that there exists a cointegration relationship between gross domestic product and exchange in Southeast Asia (Indonesia, Malaysia, and Thailand). 
Researchers also presented supportive literature relating monetary models to exchange rate determination such as that of Dutt and Ghosh (2000), Miyakoshi (2000), and Jimoh (2004). Using a variety of currencies, they all tend to support a short-run dynamic or long-run equilibrium relationship between the exchange rate and those macro fundamentals. The study by Poon (2010) suggests that there exists a relationship between exchange rates of Malaysia, Singapore, and Thailand and their respective market interest rates. The literature provides robust empirical evidence of the relationship between the level of an exchange rate and the level of commodity prices in that the latter seems to drive the former (Dumitrescu, Arezki, Freytag, \& Quintyn, 2012). Rapid, unexpected, and often large movements in commodity prices are an important feature of the behaviour of commodity prices. Chen and Rogoff (2003) provided early evidence of the relationship between commodity prices such as gold and exchange rates for a selected number of resource-rich developed economies.

\section{FINDINGS AND DISCUSSION}

Exchange rate determinants used in this paper are reported in Table 1 whilst Table 2 presents various exchange arrangements adopted by the SADC countries. South Africa, Namibia, Lesotho, and Swaziland are members of the Common Monetary Area (CMA), an agreement that provides for fixed exchange rates on par with the South African rand which is the reason why all three exchange rates are not included the analysis section. The determination of an appropriate and correctly specified ARDL model is based on test criteria such as the Schwarz Bayesian Criterion (SBC) and various diagnostic tests for econometric problems. The adjustment parameter (ECM) is directly derived from the ARDL model whose residuals should exhibit no temporal autocorrelation, be normally distributed and homoscedastic (Table 3). The ARDL specifications reported in the same table shows that the models generated are parsimonious in that most exchange rates examined are explained based on their past values and also include current or lagged values of one deterministic variable. Table 4 shows the F-statistics tests conducted as part of the analysis which is used to test the existence of long-run relationships between exchange rates and various determinants. The test involves asymptotic critical value bounds, depending on whether the variables are $\mathrm{I}(0)$ or $\mathrm{I}(1)$ or a mixture of both. Two sets of critical values are generated which one set refers to the $\mathrm{I}(1)$ series and the other for the $\mathrm{I}(0)$ series. Critical values for the $\mathrm{I}(1)$ series are referred to as upper bound critical values, while the critical values for $\mathrm{I}(0)$ series are referred to as the lower bound critical values. If the F-test statistic exceeds their respective upper critical values, we can conclude that there is evidence of a long-run relationship between the variables regardless of the order of integration of the variables. If the test statistic is below the upper critical value, we cannot reject the null hypothesis of no cointegration and if it lies between the bounds, a conclusive inference cannot be made without knowing the order of integration of the underlying regressors. F-statistic test results reported in Table 4 show that there exist significant relationships between the exchange rates reported and their respective determinants.
Table 5 presents long-run relationships as well as ECM values between exchange rates and macroeconomic fundamentals in Botswana, Madagascar, Malawi, Mauritius, Mozambique, Tanzania, Democratic Republic of Congo (DRC), and Seychelles. Two explanatory variables stand out: CPI and interest rates. The findings of this paper suggest that there is a unique relationship between the exchange rate and the consumer price index (CPI) in Angola which can be explained by the huge inflows of capital as international firms raced to take advantage of the flourishing oil industry that marked the beginning of the century. As a consequence, the country suffered from hikes in the inflation rates which resulted in a weakening local currency. The short-term results indicate that for every one-unit increase in the CPI, the kwanza exchange rate increases on average by 1.48 units. This latter finding, if viewed in conjunction with long term coefficient of (-0.287), partially explains why Luanda was the most expensive capital across the globe in 2011 (World Bank, 2010). The higher the prices, the greater the currency loss in terms of purchasing power parity which again leads to an increase in the prices. Angola's high growth rate in recent years was driven by high international prices for its oil. The country is the second-largest oil producer in Africa and became a member of the Organization of the Petroleum Exporting Countries (OPEC) in late 2006 with a production quota of 1.9 million barrels a day (Staines, 2012). Cointegrating relationships between exchange rates and the CPI also feature for the Malawi kwacha, the Mauritian rupee, the DRC franc, and Mozambique metical. For the latter, there is also a positive long term relationship between the exchange and interest rates (0.022) which bodes with the fact Mozambique remains dependent on foreign assistance for more than half of its annual budget and the majority of the population remains below the poverty line. Ideally, the relationship between international aid and exchange rates should have been investigated but this was not possible due to the unavailability of data.

This paper denotes relationships between exchange rates of the Botswana pula and GDP. Although this relationship is positive, it is very weak and shows that the macroeconomic fundamentals in Botswana provide little insight into the behaviour of exchange rates. A significant finding of this paper is the cointegrating relationship between capital accounts and the exchange rate of Madagascar's ariary. Madagascar followed a World Bank and the IMF-led policy of privatisation and liberalisation that placed the country on a slow and steady growth path from an extremely low level. Agriculture, including fishing and forestry, is a mainstay of the economy, accounting for more than one-fourth of GDP.

In Seychelles, there the author reports significant positive long-run (0.107) and short-run (0.002) relationships between exchange and interest rates. In addition, money supply seems to be positively cointegrated with the exchange rate in the long-term (0.0002) whilst negatively cointegrated with the exchange rate in the short term $(-0.00002)$. The country adopted a fixed exchange rate policy till mid-1996, hence, the focus on the period post-1996 banking reforms in Tanzania helped increase private-sector growth and investment. Findings indicate that when the interest rate increases by one unit, the exchange rate appreciates by 0.27 units 
on average. This is the highest gradient found for SADC countries in relation to a macroeconomic aggregate. In the short term, this relationship is negative $(-0.0005)$. Despite the fact that the country has registered an average GDP growth of $7 \%$ per year from 2000-2008 (CIA, 2012), it still relies on international aid from the World Bank, the IMF, and bilateral donors. As a matter of fact, in 2008 Tanzania received the World's largest Millennium Challenge Compact grant, worth US \$698 million (World Bank, 2011).

\subsection{CUSUM and CUSUSQ stability tests}

ARDL model's stability was tested using the cumulative sum (CUSUM) and CUSUM square tests. For the DRC franc (Figures 3c and 3d), Seychelles rupee (Figures $8 \mathrm{c}$ and $8 \mathrm{~d}$ ), and Tanzania shilling (Figures 9c and 9d) the recursive residuals are independently and randomly distributed and do not exhibit a tendency to cumulatively increase or decrease throughout the sample. Angola kwanza (Figures 1c and 1d), Madagascar ariary (Figures 4c and 4d), Malawi kwacha (Figures 5c and 5d), and Mozambique metical (Figures $7 \mathrm{c}$ and $7 \mathrm{~d}$ ) stability tests' exhibit a continuous break. Botswana pula (Figures 2c and 2d), Mauritius rupee (Figures 6c and $6 \mathrm{~d}$ ) exhibit a single break throughout the same period. This shows evidence that the ARDL model parameters are not constant for the exchange rates of Angola, Botswana, Madagascar, Malawi, Mauritius, Mozambique, while the DRC, Seychelles, and Tanzania CUSUM and CUSUMSQ tests graphs reveal model stability at breakpoints.

\subsection{Forecasting performance}

Table 7 reports forecasting results generated using the ARDL models presented in Table 4 and Table 5 . The forecasts generated up to 2008 - pre-crisis period - show that the cointegration approach used in this paper performed considerably well with mean absolute percentage error (MAPE) values are well below $10 \%$, which are regarded as "highly accurate forecasting" (Lewis, 1982). This comes with a slight contrast with the dynamic forecasts generated over a period of 18 months from January 2009 to June 2010 with relatively high MAPE values of $8.75 \%$ and $2.89 \%$ for Angola and Malawi respectively. In Botswana, the DRC, Madagascar, Mauritius, Mozambique, Seychelles, and Tanzania ARDL generated accurate forecasts overall with MAPEs of $1.19 \%, 1.96 \%, 1.45 \%$, $1.08 \%, 1.07 \%, 1.78 \%$, and $1.17 \%$ respectively. This confirms the assumption that SADC countries have come a long way since the dark years of civil wars in terms of strengthening their macroeconomic fundamentals. It also consolidates the assumption of inter-regional similarity in that a bloc of countries seems to react in the same way to sudden shocks affecting respective exchange rates.

\section{CONCLUSION}

This paper examined the relationship between exchange rates and fundamentals in Africa with a particular focus on SADC using the ARDL cointegration approach. The method delivers good results for most exchange rates indicating that countries in the region reached a certain stage of development as changes in exchange rates seem to respond to changes in macroeconomic aggregates. That said, Angola, Malawi Mauritius, Mozambique, the DRC are struggling with inflation which is an issue yet to be addressed ahead of the single currency project in 2021. Findings on consumer price inflation suggest that the chances of SADC member countries fulfilling the requirements of a currency union are quite low.

The authors believe that there is still a useful role for trade flows to be played in the asset approach to exchange rate determination since the latter have implications on financial asset flows. If the balance of trade deficits are financed by depleting domestic stocks of foreign currency and trade surpluses are associated with increases in the domestic holding of foreign money, we can see the catalyst role played by the trade accounts. If the exchange rate adjusts so that the stocks of domestic and foreign money are willingly held, then the country with a trade surplus will be accumulating foreign currency. As holdings of foreign money increase relative to the local currency, the relative value of foreign money will fall or the foreign currency will depreciate whilst the local currency appreciates. This paper examined trade and non-trade variables as determinants of exchange rate fluctuations in the SADC region. Traditionally, studies that used ARDL cointegration for exchange rate determination investigated the relationship of the latter with macroeconomic variables - namely interest rates, trade balance, inflation rates, and GDP changes. This means that by nature, ARDL cannot be applied to countries that do not record the progress of their macroeconomic performance. Therefore, if the ARDL cointegration method delivers good results for any currency, then this is one sign that the country in question reached a certain stage of development that enables better scrutiny to work out relationships across national aggregates. In this research, fundamentals that cause changes in the exchange rates of various emerging markets were discussed. Overall, exchange rates examined in this paper have been affected by trade variables and this assumption is valid across all SADC countries. In contrast, to what is happening in advanced economies such as the US, the UK, and EU countries, trade flows still play an eminent role in the determination of exchange rates in SADC. The focus of attention is on the trade account mainly because when the traditional theory of exchange rate determination was developed, capital flows were restricted enough so as not to enter the argument and that is still the case in the African continent. Capital flows were treated as exogenous shocks rather than as being endogenous to the model. This approach is very different from the modern asset view of the exchange rate where the exchange rate is treated as the price of an asset (relative price of two monies)

One of the novel elements of this research was a contribution to the literature in terms of identifying a set of macro-economic fundamentals that dictate changes of exchange rate movements both in the long and short-run. Limitations of this paper can be summarised in the fact that most exchange rates that were examined are not freely floating and thus do not respond solely to the forces of the market. Another limitation is the challenge 
faced by the authors to collect a consistent set of macro-economic variables for all sampled countries which would have rendered comparisons between countries more revealing. Authors had to rely on existing data to inform the research project and there was little choice in terms of expanding the study further to include more financial data that are both relevant and fit for the purpose.

\section{REFERENCES}

1. AbuDalu, A., \& Almasaied, S. W. (2011). The purchasing power parity of ASEAN-5 against Europe exchange rate: Evidence using autoregressive distributed lag. Association of Korean Economic Studies. Retrieved from http://www.akes.or.kr/eng/papers(2012)/10.full.pdf

2. Achsani, N. A. (2010). Stability of money demand in an emerging market economy: An error correction and ARDL model for Indonesia. Research Journal of International Studies, 13, 56-62. Retrieved from http://achsani.blog.mb.ipb.ac.id/files/2010/08/rjis_13_05.pdf

3. Adebiyi, M. A. (2007). An evaluation of foreign exchange intervention and monetary aggregates in Nigeria (1986-2003) (MPRA Paper No. 3817). Retrieved from https://mpra.ub.uni-muenchen.de/id/eprint/3817

4. Adeniyi, O., Omisakin, O., \& Oyinlola, A. (2011). Exchange rate and trade balance in West-African monetary zone: Is there a J-curve? The International Journal of Applied Economics and Finance, 5(3), 167-176. https://doi.org/10.3923/ijaef.2011.167.176

5. Akinlo, A. E. (2006). The stability of money demand in Nigeria: An autoregressive distributed lag approach. Journal of Policy Modeling, 28(4), 445-452. https://doi.org/10.1016/j.jpolmod.2005.09.001

6. Apeh, K., Auwal, A. M., \& Obinna, N. N. (2019). An econometric assessment of the impact of exchange rate depreciation on inflation in Nigeria (1981-2017). Preprints, 2019010289. https://doi.org/10.20944/preprints201901.0289.v1

7. Asongu, S., Folarin, O., \& Biekpe, N. (2019). The stability of demand for money in the proposed Southern African Monetary Union. International Journal of Emerging Markets, 15(2), 222-244. https://doi.org/10.1108/IJOEM-082018-0443

8. Auwal, U. (2010). GARCH and ARDL model of exchange rate: Evidence from Nigeria's Retail Dutch Auction System. International Research Journal of Finance and Economics, 49, 7-14. Retrieved from https://www.researchgate.net/publication/294492485_GARCH_and_ARDL_model_of_exchange_rate_Evidence_f rom_Nigeria's_retail_Dutch_Auction_System

9. Baharumshah, A. Z., Mohd, S. H., \& Masih, A. M. M. (2009). The stability of money demand in China: Evidence from the ARDL model. Economic Systems, 33(3), 231-244. https://doi.org/10.1016/j.ecosys.2009.06.001

10. Bahmani-Oskooee, M. (2001). Nominal and real effective exchange rates of middle eastern countries and their trade performance. Applied Economics, 33(1), 103-111. https://doi.org/10.1080/00036840122490

11. Bahmani-Oskooee, M., \& Rehman, H. (2005). Stability of the money demand function in Asian developing countries. Applied Economics, 37(7), 773-792. https://doi.org/10.1080/0003684042000337424

12. Belle, M. (2010). Regional economic integration in SADC: Progress, prospects and statistical issues for monetary union. In Irving Fisher Committee on central bank statistics (IFC Bulletin No. 32, pp. 85-95). Retrieved from https://www.bis.org/ifc/publ/ifcb32.pdf

13. Brandt, H., Gsanger, H., Otzen, U., \& Qualmann, R. (2000). Approaches to promote regional integration in the Southern African development community (SADC) (Berichte und Gutachten No. 6/2000). Retrieved from http://edoc.vifapol.de/opus/volltexte/2013/4042/pdf/BuG_6_2000_DE.pdf

14. Breitenbach, M. C., Zerihun, M. F., \& Kasongo, A. T. (2020). Empirical analyses of the relationship between real exchange rate and real interest rate differentials in inflation targeting countries. African Journal of Business and Economic Research, 15(1), 7-25. https://doi.org/10.31920/1750-4562/2020/15nlal

15. Brown, R. L., Durbin, J., \& Evans, J. M. (1975). Techniques for testing the constancy of regression relationships over time. Journal of the Royal Statistical Society. Series B (Methodological), 37(2), 149-192. https://doi.org/10.1111/j.25176161.1975.tb01532.x

16. Cameron, S. (2005). Econometrics. Berkshire, England: McGraw Hill Education.

17. Cavoli, T. (2008). The exchange rate and optimal monetary policy rules in open and developing economies: Some simple analytics. Economic Modelling, 25(5), 1011-1021. https://doi.org/10.1016/j.econmod.2008.01.006

18. Central Intelligence Agency. CIA. (2012). The world factbook. Retrieved from https://www.cia.gov/library/publications /the-world-factbook/

19. Chen, Y.-C., \& Rogoff, K. (2003). Commodity currencies. Journal of International Economics, 60(1), 133-160. https://doi.org/10.1016/S0022-1996(02)00072-7

20. Dahir, A. M., Mahat, F., Bany-Ariffin, \& Ab Razak, N. H. (2017). The real exchange rate-foreign direct investment controversy in South Africa: An application of ARDL approach. Internationlal Journal of Economics and Finance, 9(11), 207-217. https://doi.org/10.5539/ijef.v9n11p207

21. Duasa, J. (2007). Determinants of Malaysian trade balance: An ARDL bound testing approach. Global Economic Review, 36(1), 89-102. https://doi.org/10.1080/12265080701217405

22. Dumitrescu, E., Arezki, R., Freytag, A., \& Quintyn, M. G. (2012). Commodity prices and exchange rate volatility: Lessons from South Africa's capital account liberalisation (IMF Working Paper No. 12/168). Retrieved from https://www.imf.org/en/Publications/WP/Issues/2016/12/31/Commodity-Prices-and-Exchange-Rate-VolatilityLessons-from-South-Africas-Capital-Account-26026

23. Dutt, S., \& Ghosh, D. (2000). An empirical note on the monetary exchange rate model. Applied Economics Letters, 7(10), 669-671. https://doi.org/10.1080/135048500415996

24. ECA. (2008). Assessing regional integration in Africa III: Towards monetary and financial integration in Africa (United Nations Economic Commission for Africa, 1-312). Retrieved from https://www.uneca.org/publications/assessingregional-integration-africa-iii

25. Engle, R. F., \& Granger, C. W. J. (1987). Co-integration and error correction: Representation, estimation and testing. Econometrica, 55(2), 251-276. https://doi.org/10.2307/1913236

26. Engle, R. F., \& Yoo, B. S. (1987). Forecasting and testing in co-integrated systems. Journal of Econometrics, 35(1), 143-159. https://doi.org/10.1016/0304-4076(87)90085-6

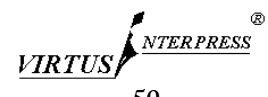


27. Freund, C., \& Bolaky, B. (2008). Trade, regulations, and income. Journal of Development Economics, 87(2), 309321. https://doi.org/10.1016/j.jdeveco.2007.11.003

28. Granger, C. W. J. (1981). Some properties of time series data and their use in econometric model specification. Journal of Econometrics, 16(1), 121-130. https://doi.org/10.1016/0304-4076(81)90079-8

29. Hallwood, P., \& MacDonald, R. (2000). International money and finance (3rd ed.). Oxford, England: Wiley-Blackwell.

30. Himarios, D. (1989). Devaluations improve the trade balance? The evidence revisited. Economic Inquiry, 27(1), 143-168. https://doi.org/10.1111/j.1465-7295.1989.tb01169.x

31. International Monetary Fund. IMF. (2018). Annual report on exchange arrangements and exchange restrictions. Retrieved from https://www.imf.org/en/Publications/Annual-Report-on-Exchange-Arrangements-and-ExchangeRestrictions/Issues/2019/04/24/Annual-Report-on-Exchange-Arrangements-and-Exchange-Restrictions-2018-46162

32. Iyke, B., N., \& Odhiambo, N. M. (2017). Foreign exchange markets and the purchasing power parity theory: Evidence from two Southern African countries. African Journal of Economic and Management Studies, 8(1), 89102. https://doi.org/10.1108/AJEMS-03-2017-147

33. Jeffries, K. R. (2007), The process of monetary integration in the SADC region. Journal of Southern African Studies, 33(1), 83-106. https://doi.org/10.1080/03057070601136590

34. Jimoh, A. (2004). The monetary approach to exchange rate determination: Evidence from Nigeria. Journal of Economic Cooperation, 25(2), 109-130. Retrieved from https://www.sesric.org/files/article/109.pdf

35. Johansen, S. (1988). Statistical analysis of cointegration vectors. Journal of Economic Dynamics and Control, 12(2-3), 231-254. https://doi.org/10.1016/0165-1889(88)90041-3

36. Lewis, C. D. (1982). Industrial and business forecasting methods: A practical guide to exponential smoothing and curve fitting. London, England: Butterworth Scientific.

37. Lin, C.-H. (2012). The comovement between exchange rates and stock prices in the Asian emerging markets. International Review of Economics and Finance, 22(1), 161-172. https://doi.org/10.1016/j.iref.2011.09.006

38. Long, D., \& Samreth, S. (2008). The monetary model of exchange rate: Evidence from the Philippines using ARDL approach. Economics Bulletin, 6(31), 1-13. Retrieved from https://core.ac.uk/download/pdf/6481171.pdf

39. Mair, S., \& Christian, P. B. (2001). Regional integration and cooperation in Sub-Saharan Africa: Case study of EAC, ECOWAS and SADC (Research report by the Federal Ministry for Economic Cooperation and Development). Bonn.

40. Motelle, S., \& Biekpe, N. (2015). Financial integration and stability in the Southern African development community. Journal of Economics and Business, 79, 100-117. https://doi.org/10.1016/j.jeconbus.2015.01.002

41. Miyakoshi, T. (2000). The monetary approach to the exchange rate: Empirical observations from Korea. Applied Economics Letters, 7(12), 791-794. https://doi.org/10.1080/135048500444813

42. Odhiambo, N. M. (2014). Electricity consumption, exports, and economic growth in the Democratic Republic of Congo: An ARDL-Bounds testing approach. The Journal of Developing Areas, 48(4), 189-207. https://doi.org/10.1353/jda.2014.0069

43. Pesaran, H., \& Pesaran, B. (2009). Time series econometrics: Using Microfit 5.0. Oxford, England: Oxford University Press.

44. Pesaran, M. H., \& Shin, Y. (1995). Long-run structural modelling (Cambridge Working Papers in Economics No. 9419). Faculty of Economics, University of Cambridge.

45. Pesaran, M. H., \& Shin, Y. (1999). An autoregressive distributed lag-modelling approach to cointegration. In S. Strøm (Ed.), Econometrics and economic theory in the 20th century: The Ragnar Frisch Centennial Symposium (Econometric Society Monographs, pp. 371-413). Cambridge, England: Cambridge University Press. https://doi.org/10.1017/CCOL521633230.011

46. Pesaran, M. H., Shin, Y., \& Smith, R. J. (2001). Bounds testing approaches to the analysis of level relationships. Journal of Applied Econometrics, 16(3), 289-326. https://doi.org/10.1002/jae.616

47. Peters, W.-C. (2010). The quest for an African economic community: Regional integration and its role in achieving African unity - The case of SADC (European University Studies, Vol. 591). Frankfurt, Germany: Peter Lang $\mathrm{GmbH}$, Internationaler Verlag der Wissenschaften.

48. Poon, W. C. (2010). Augmented MCI: An indicator of monetary policy stance for ASEAN-5? (Monash Economics Working Paper No. 25/10). Monash University. Retrieved from https://www.researchgate.net/publication /46443085_Augmented_MCi_AN_Indicator_Of_Monetary_Policy_Stance_For_ASEAN-5

49. Redda, E. H., \& Muzindusti, P. F. (2017). Does SADC constitute an optimum currency area? Evidence from generalised purchasing power parity. Proceedings of the 8th Economics \& Finance Conference, London. https://doi.org/10.20472/EFC.2017.008.007

50. Redda, E. H., Muzindusti, P. F., \& Grobler, W. (2017). Analysis of feasibility of monetary union in the SADC and EAC: Evidence from analysis of trade openness. International Journal of Economics and Finance Studies, 9(2), 3247. Retrieved from https://dergipark.org.tr/en/pub/ijefs/issue/36092/405274

51. Samreth, S. (2008). Estimating money demand function in Cambodia: ARDL Approach (MPRA Paper No. 16274). Retrieved from https://mpra.ub.uni-muenchen.de/16274/

52. Sekantsi, L. (2011). The impact of real exchange rate volatility on South African exports to the United States (U.S.): A bounds test approach. Review of Economic and Business Studies, 4(2), 119-139. Retrieved from http://rebs.feaa.uaic.ro/issues/pdfs/8.pdf\#page $=119$

53. Shahbaz, M., Awan, R. U., \& Ahmad, K. (2011). The exchange value of the Pakistan rupee and Pakistan trade balance: An ARDL bounds testing approach. The Journal of Developing Areas, 44(2), 69-93. https://doi.org/10.1353/jda.0.0108

54. Staines, N. (2012). Interview with Rumo. Interview with the IMF Resident Representative in Angola, Luanda. Retrieved from IMF website: http://www.imf.org/external/country/ago/index.htm

55. Türsoy, T. (2017). Causality between stock prices and exchange rates in Turkey: Empirical evidence from the ARDL bounds test and a combined cointegration approach. International Journal of Financial Studies, 5(1), 1-10. https://doi.org/10.3390/ijfs5010008

56. World Bank. (2002). Globalization, growth and poverty: Building an inclusive world economy (A World Bank Policy Research Report No. 23591). Washington, D.C.: The World Bank. Retrieved from http://documents1 .worldbank.org/curated/en/954071468778196576/pdf/multi0page.pdf

57. World Bank. (2010). The global competitiveness report 2010-2011. Retrieved from http://www3.weforum.org/docs /WEF_GlobalCompetitivenessReport_2010-11.pdf

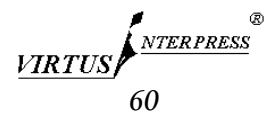


58. World Bank. (2011). World development report 2011: Conflict, security, and development. Retrieved from http://hdl.handle.net/10986/4389

59. Yanikkaya, H. (2003). Trade openness and economic growth: A cross-country empirical investigation. Journal of Development Economics, 72(1), 57-89. https://doi.org/10.1016/S0304-3878(03)00068-3

60. Yin, W., \& Li, J. (2014). Macroeconomic fundamentals and the exchange rate dynamics: A no-arbitrage macro-finance approach. Journal of International Money and Finance, 41, 46-64. https://doi.org/10.1016/j.jimonfin.2013.10.004

61. Zakaria, M., \& Ghauri, A. B. (2011). Trade openness and real exchange rate: Some evidence from Pakistan. The Romanian Economic Journal, 39, 201-229. Retrieved from http://www.rejournal.eu/sites/rejournal.versatech.ro /files/issues/2011-03-01/561/zakaria20-20je2039.pdf

62. Zerihun, M. F., \& Breitenbach, M. C. (2017). Panel data analysis of the proposed monetary union in the Southern African development community. SPOUDAI Journal of Economics and Business, 67(4), 23-44. Retrieved from https://repository.up.ac.za/bitstream/handle/2263/74064/Zerihun_Panel_2017.pdf?sequence=1\&isAllowed=y

\section{APPENDIX}

Table 1. Exchange rate determinants in SADC countries

\begin{tabular}{|l|l|l|}
\hline \multicolumn{1}{|c|}{ Currency name } & \multicolumn{1}{c|}{ Trade variables } \\
\hline Angola kwanza & Exports & Capital account, oil price, interest rate and CPI \\
\hline Botswana pula & Exports, TB, TO & GDP and interest rate \\
\hline Congo franc & Exports, imports and TB & CPI \\
\hline Madagascar ariary & Exports, imports and TB & Capital account and CPI \\
\hline Malawi kwacha & Exports, imports and TB & Capital account and CPI \\
\hline Mauritius rupee & Exports, imports and TB & Interest rates \\
\hline Mozambique metical & N/A & Capital reserves, interest rate and CPI \\
\hline Seychelles rupee & Exports, Imports and TB & Money supply and interest rate \\
\hline South Africa rand & Exports, Imports and TB & Interest rate and money supply \\
\hline Tanzania shilling & Exports, Imports and TB & Interest rate \\
\hline Zambia kwacha & Exports, Imports and TB & Interest rate and CPI \\
\hline Zimbabwe dollar & N/A & N/A \\
\hline
\end{tabular}

Note: TB - Trade balance; TO - Trade openness; GDP - Gross domestic product; CPI - Consumer price index.

Table 2. Exchange rate arrangements in SADC

\begin{tabular}{|l|l|l|}
\hline \multicolumn{1}{|c|}{ SADC currencies } & \multicolumn{1}{c|}{ Currency code } & \multicolumn{1}{c|}{ Regimes } \\
\hline Angola kwanza & AOA & Stabilized arrangement \\
\hline Botswana pula & BWP & Crawling peg \\
\hline Congo franc & CDF & Other managed arrangement \\
\hline Lesotho loti & LSL & Conventional peg \\
\hline Madagascar ariary & MGA & Floating \\
\hline Malawi kwacha & MWK & Stabilized arrangement \\
\hline Mauritius rupee & MUR & Floating \\
\hline Mozambique metical & MZN & Floating \\
\hline Namibia dollar & NAD & Conventional peg \\
\hline Seychelles rupee & SCR & Floating \\
\hline Swaziland lilangeni & SZL & Conventional peg \\
\hline South Africa rand & ZAR & Floating \\
\hline Tanzania shilling & TZS & Stabilized arrangement \\
\hline Zambia kwacha & ZMW & Floating \\
\hline Zimbabwe dollar & ZWD & Other managed arrangement \\
\hline
\end{tabular}
Source: Annual Report on Exchange Arrangements and Exchange Restrictions (IMF, 2018).

Table 3. Diagnostic tests of estimated models

\begin{tabular}{|l|l|l|l|l|}
\hline \multicolumn{1}{|c|}{ Currency name } & \multicolumn{1}{c|}{ Specification } & \multicolumn{1}{c|}{$\boldsymbol{X}_{\text {Autocorrelation }}^{\mathbf{2}}$} & \multicolumn{1}{c|}{$\boldsymbol{X}_{\text {Normality }}^{\mathbf{2}}$} & \multicolumn{1}{c|}{$\boldsymbol{X}_{\text {Heteroscedasticity }}$} \\
\hline Angola kwanza & ARDL(2,1) & 6.727 & $145.822^{*}$ & $155.540^{*}$ \\
\hline Botswana pula & ARDL(1,0) & 15.894 & $41.663^{*}$ & 0.520 \\
\hline DRC franc & ARDL(1,1) & 13.284 & $34.052^{*}$ & 2.020 \\
\hline Madagascar ariary & ARDL(1,0) & 13.055 & $66.520^{*}$ & 0.565 \\
\hline Malawi kwacha & ARDL(2,0) & 20.478 & $77.950^{*}$ & 0.738 \\
\hline Mauritius rupee & ARDL(1,0) & 13.291 & $162.639^{*}$ & 0.124 \\
\hline Mozambique metical & ARDL(1,0) & 19.711 & $12.757^{*}$ & 3.819 \\
\hline Seychelles rupee & ARDL(2,3,0) & $37.887^{*}$ & 1.762 \\
\hline Tanzania shilling & ARDL(1,0) & 18.0479 & & 0.281 \\
\hline
\end{tabular}

Note: * and ${ }^{* *}$ denote significance at $1 \%$ and $5 \%$ respectively. 
Table 4. ARDL bounds F-tests

\begin{tabular}{|l|l|l|}
\hline \multicolumn{1}{|c|}{ Currency name } & \multicolumn{1}{|c|}{ Specification } & \multicolumn{1}{c|}{ F-statistic } \\
\hline Angola kwanza & $E x_{A N K}(\mathrm{CPI})$ & $\mathrm{F}(2,97) 25.061^{*}$ \\
\hline Botswana pula & $\log E x_{B W P}(\mathrm{GDP})$ & $\mathrm{F}(2,161) 2.591^{* *}$ \\
\hline DRC franc & $\log E x_{C D F}(\log \mathrm{CPI})$ & $\mathrm{F}(1,166) 29.628^{*}$ \\
\hline Madagascar ariary & $\log E x_{M G A}(\mathrm{Capital}$ Account) & $\mathrm{F}(1,342) 1.283^{* *}$ \\
\hline Malawi kwacha & $\log E x_{M W K}(\mathrm{CPI})$ & $\mathrm{F}(2,260) 2.874^{* *}$ \\
\hline Mauritius rupee & $\log E x_{M U R}(\mathrm{CPI})$ & $\mathrm{F}(1,342) 2.880^{*}$ \\
\hline Mozambique metical & $\log E x_{M Z N}($ logreserves, CPI, Interest Rate) & $\mathrm{F}(5,157) 7.741^{*}$ \\
\hline Seychelles rupee & $\log E x_{S C R}$ (Money Supply, Interest Rate) & $\mathrm{F}(5,127) 17.273^{*}$ \\
\hline Tanzania shilling & $\log E x_{T Z S}$ (Interest Rate) & $\mathrm{F}(1,152) 6.651^{* *}$ \\
\hline
\end{tabular}
Note: * and ** denote significance at $1 \%$ and $5 \%$ respectively.

Table 5. SADC long-run cointegration coefficients

\begin{tabular}{|c|c|c|c|}
\hline \multicolumn{4}{|c|}{ Botswana pula (logs) } \\
\hline \multicolumn{4}{|c|}{$A R D L(1,0)$} \\
\hline Variable & Coefficient & t-ratio & Significance \\
\hline GDP & 0.00004 & 4.666 & 0.000 \\
\hline Constant & 1.606 & 14.238 & 0.000 \\
\hline ECM(-1) & -0.046 & -2.215 & 0.028 \\
\hline \multicolumn{4}{|c|}{ Madagascar ariary (logs) } \\
\hline \multicolumn{4}{|c|}{$A R D L(1,0)$} \\
\hline Variable & Coefficient & t-ratio & Significance \\
\hline Capital Account & 0.039 & 3.005 & 0.003 \\
\hline ECM(-1) & 0.002 & 4.293 & 0.000 \\
\hline \multicolumn{4}{|c|}{ Malawi kwacha (logs) } \\
\hline \multicolumn{4}{|c|}{$A R D L(2,0)$} \\
\hline Variable & Coefficient & t-ratio & Significance \\
\hline $\mathrm{CPI}$ & 0.046 & 4.573 & 0.000 \\
\hline ECM(-1) & 0.010 & 3.329 & 0.001 \\
\hline \multicolumn{4}{|c|}{ Mauritius rupee (logs) } \\
\hline \multicolumn{4}{|c|}{$A R D L(1,0)$} \\
\hline Variable & Coefficient & t-ratio & Significance \\
\hline CPI & 0.023 & 2.278 & 0.023 \\
\hline $\operatorname{ECM}(-1)$ & 0.002 & 2.569 & 0.011 \\
\hline \multicolumn{4}{|c|}{ Mozambique metical (logs) } \\
\hline \multicolumn{4}{|c|}{$A R D L(2,0,0,0)$} \\
\hline Variable & Coefficient & t-ratio & Significance \\
\hline Log Capital Reserves & 0.496 & 14.266 & 0.000 \\
\hline CPI & -0.034 & -2.959 & 0.004 \\
\hline Interest Rate & 0.022 & 3.969 & 0.000 \\
\hline Time Trend & 0.027 & 3.479 & 0.001 \\
\hline $\operatorname{ECM}(-1)$ & -0.047 & -3.043 & 0.003 \\
\hline \multicolumn{4}{|c|}{ Tanzania shilling (logs) } \\
\hline \multicolumn{4}{|c|}{$A R D L(1,0)$} \\
\hline Variable & Coefficient & t-ratio & Significance \\
\hline Interest Rate & 0.268 & 5.327 & 0.000 \\
\hline ECM(-1) & 0.002 & 3.582 & 0.000 \\
\hline \multicolumn{4}{|c|}{ DRC franc (logs) } \\
\hline \multicolumn{4}{|c|}{$A R D L(1,1)$} \\
\hline Variable & Coefficient & t-ratio & Significance \\
\hline Log CPI & 1.714 & 4.709 & 0.000 \\
\hline $\operatorname{ECM}(-1)$ & -0.012 & -3.277 & 0.001 \\
\hline \multicolumn{4}{|c|}{ Seychelles rupee (logs) } \\
\hline \multicolumn{4}{|c|}{$A R D L(2,3,0)$} \\
\hline Variable & Coefficient & t-ratio & Significance \\
\hline Interest Rate & 0.107 & 8.152 & 0.000 \\
\hline Money Supply & 0.0002 & 6.302 & 0.000 \\
\hline $\mathrm{ECM}(-1)$ & -0.026 & -2.224 & 0.028 \\
\hline
\end{tabular}


Table 6. SADC short-run cointegration coefficients

\begin{tabular}{|c|c|c|c|}
\hline \multicolumn{4}{|c|}{ Angola kwanza } \\
\hline \multicolumn{4}{|c|}{$A R D L(1,0)$} \\
\hline Variable & Coefficient & t-ratio & Significance \\
\hline$\Delta \mathrm{CPI}$ & 1.481 & 4.271 & 0.000 \\
\hline DW-statistic & 2.6062 & & \\
\hline Log-likelihood & -219.361 & & \\
\hline Schwarz Bayesian Criterion & -228.572 & & \\
\hline \multicolumn{4}{|c|}{ Botswana pula (logs) } \\
\hline \multicolumn{4}{|c|}{$\operatorname{ARDL}(1,0)$} \\
\hline Variable & Coefficient & t-ratio & Significance \\
\hline$\Delta \mathrm{GDP}$ & 0.000002 & 2.208 & 0.029 \\
\hline Constant & 0.075 & 2.303 & 0.023 \\
\hline DW-statistic & 2.070 & & \\
\hline Log-likelihood & 339.514 & & \\
\hline Schwarz Bayesian Criterion & 331.864 & & \\
\hline \multicolumn{4}{|c|}{ Madagascar ariary (logs) } \\
\hline \multicolumn{4}{|c|}{$A R D L(1,0)$} \\
\hline Variable & Coefficient & t-ratio & Significance \\
\hline$\Delta$ Capital Account & -0.00009 & -2.239 & 0.026 \\
\hline DW-statistic & 1.830 & & \\
\hline Log-likelihood & 541.913 & & \\
\hline Schwarz Bayesian Criterion & 536.072 & & \\
\hline \multicolumn{4}{|c|}{ Malawi kwacha (logs) } \\
\hline \multicolumn{4}{|c|}{$A R D L(2,0)$} \\
\hline Variable & Coefficient & t-ratio & Significance \\
\hline$\Delta \mathrm{CPI}$ & -0.0004 & -2.188 & 0.030 \\
\hline DW-statistic & 1.992 & & \\
\hline Log-likelihood & 354.738 & & \\
\hline Schwarz Bayesian Criterion & 356.380 & & \\
\hline \multicolumn{4}{|c|}{ Mozambique metical (logs) } \\
\hline \multicolumn{4}{|c|}{$A R D L(2,0,0,0)$} \\
\hline Variable & Coefficient & t-ratio & Significance \\
\hline$\Delta$ Log Capital Reserves & 0.023 & 3.449 & 0.001 \\
\hline$\Delta \mathrm{CPI}$ & -0.001 & -3.975 & 0.000 \\
\hline$\Delta$ Interest Rate & 0.001 & 3.942 & 0.000 \\
\hline Time Trend & 0.001 & 4.108 & 0.000 \\
\hline DW-statistic & 1.863 & & \\
\hline Log-likelihood & 380.675 & & \\
\hline Schwarz Bayesian Criterion & 365.393 & & \\
\hline \multicolumn{4}{|c|}{ Tanzania shilling (logs) } \\
\hline \multicolumn{4}{|c|}{$A R D L(1,0)$} \\
\hline Variable & Coefficient & t-ratio & Significance \\
\hline$\Delta$ Interest Rate & -0.0005 & -2.589 & 0.011 \\
\hline DW-statistic & 1.804 & & \\
\hline Log-likelihood & 366.071 & & \\
\hline Schwarz Bayesian Criterion & 361.034 & & \\
\hline \multicolumn{4}{|c|}{ DRC franc (logs) } \\
\hline \multicolumn{4}{|c|}{$\operatorname{ARDL}(1,1)$} \\
\hline Variable & Coefficient & t-ratio & Significance \\
\hline$\Delta \mathrm{CPI}$ & -0.231 & -3.878 & 0.000 \\
\hline DW-statistic & 2.169 & & \\
\hline Log-likelihood & 69.471 & & \\
\hline Schwarz Bayesian Criterion & 60.785 & & \\
\hline \multicolumn{4}{|c|}{ Seychelles rupee (logs) } \\
\hline \multicolumn{4}{|c|}{$\operatorname{ARDL}(2,3,0)$} \\
\hline Variable & Coefficient & t-ratio & Significance \\
\hline$\Delta$ Interest Rate & 0.002 & 2.171 & 0.032 \\
\hline$\Delta$ Money Supply & -0.00002 & -2.155 & 0.033 \\
\hline$\Delta$ Money Supply(-1) & -0.00002 & -2.122 & 0.036 \\
\hline$\Delta$ Money Supply(-2) & -0.00005 & -4.358 & 0.000 \\
\hline DW-statistic & 1.883 & & \\
\hline Log-likelihood & 358.303 & & \\
\hline Schwarz Bayesian Criterion & 341.187 & & \\
\hline
\end{tabular}


Table 7. ARDL models forecasting performance

\begin{tabular}{|c|c|c|}
\hline \multicolumn{3}{|c|}{ Angola kwanza } \\
\hline & $\begin{array}{c}\text { Estimation period } \\
2000 \mathrm{M} 9 \text { to } 2008 \mathrm{M} 12\end{array}$ & $\begin{array}{c}\text { Forecast period } \\
2009 \mathrm{M} 1 \text { to } 2010 \mathrm{M} 6\end{array}$ \\
\hline MAPE & $1.58 \%$ & $8.75 \%$ \\
\hline \multicolumn{3}{|c|}{ Botswana pula } \\
\hline & $\begin{array}{c}\text { Estimation period } \\
\text { 1995M5 to } 2008 \mathrm{M} 12\end{array}$ & $\begin{array}{c}\text { Forecast period } \\
\text { 2009M1 to 2010M6 }\end{array}$ \\
\hline MAPE & $1.05 \%$ & $1.19 \%$ \\
\hline \multicolumn{3}{|c|}{ DRC franc } \\
\hline & $\begin{array}{c}\text { Estimation period } \\
\text { 1995M1 to 2008M12 }\end{array}$ & $\begin{array}{c}\text { Forecast period } \\
\text { 2009M1 to 2010M6 }\end{array}$ \\
\hline MAPE & $1.20 \%$ & $1.96 \%$ \\
\hline \multicolumn{3}{|c|}{ Madagascar ariary } \\
\hline & $\begin{array}{c}\text { Estimation period } \\
1990 \mathrm{M} 1 \text { to } 2008 \mathrm{M} 12\end{array}$ & $\begin{array}{c}\text { Forecast period } \\
2009 \mathrm{M} 1 \text { to } 2010 \mathrm{M} 6\end{array}$ \\
\hline MAPE & $1.05 \%$ & $1.45 \%$ \\
\hline \multicolumn{3}{|c|}{ Malawi kwacha } \\
\hline & $\begin{array}{c}\text { Estimation period } \\
\text { 1990M1 to } 2008 \mathrm{M} 12\end{array}$ & $\begin{array}{c}\text { Forecast period } \\
2009 \mathrm{M} 1 \text { to } 2010 \mathrm{M} 6\end{array}$ \\
\hline MAPE & $1.07 \%$ & $2.89 \%$ \\
\hline \multicolumn{3}{|c|}{ Mauritius rupee } \\
\hline & $\begin{array}{c}\text { Estimation period } \\
1994 \mathrm{M1} \text { to } 2008 \mathrm{M} 12\end{array}$ & $\begin{array}{c}\text { Forecast period } \\
\text { 2009M1 to 2010M6 }\end{array}$ \\
\hline MAPE & $1.028 \%$ & $1.08 \%$ \\
\hline \multicolumn{3}{|c|}{ Mozambique metical } \\
\hline & $\begin{array}{c}\text { Estimation period } \\
\text { 1995M6 to } 2008 \mathrm{M} 12\end{array}$ & $\begin{array}{c}\text { Forecast period } \\
2009 \mathrm{M} 1 \text { to } 2010 \mathrm{M} 6\end{array}$ \\
\hline MAPE & $1.03 \%$ & $1.07 \%$ \\
\hline \multicolumn{3}{|c|}{ Seychelles rupee } \\
\hline & $\begin{array}{c}\text { Estimation period } \\
1997 \mathrm{M} 1 \text { to } 2008 \mathrm{M} 12\end{array}$ & $\begin{array}{c}\text { Forecast period } \\
\text { 2009M1 to 2010M6 }\end{array}$ \\
\hline MAPE & $1.02 \%$ & $1.78 \%$ \\
\hline \multicolumn{3}{|c|}{ Tanzania shilling } \\
\hline & $\begin{array}{c}\text { Estimation period } \\
\text { 1995M6 to 2008M12 }\end{array}$ & $\begin{array}{c}\text { Forecast period } \\
\text { 2009M1 to 2010M6 }\end{array}$ \\
\hline MAPE & $1.04 \%$ & $1.17 \%$ \\
\hline
\end{tabular}

Figure 1a. Angola Kwanza Exchange Rates from 1990 to 2010

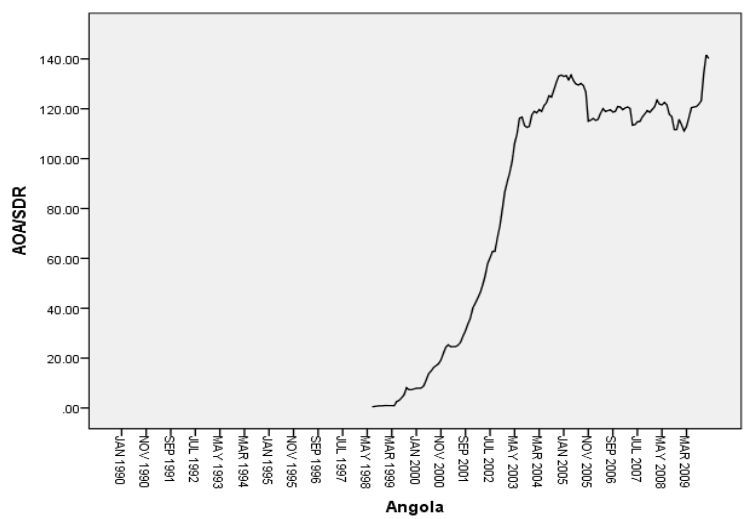

Figure 1b. Angola Kwanza Forecasts

Dynamic forecasts for the level of EXCHANGE

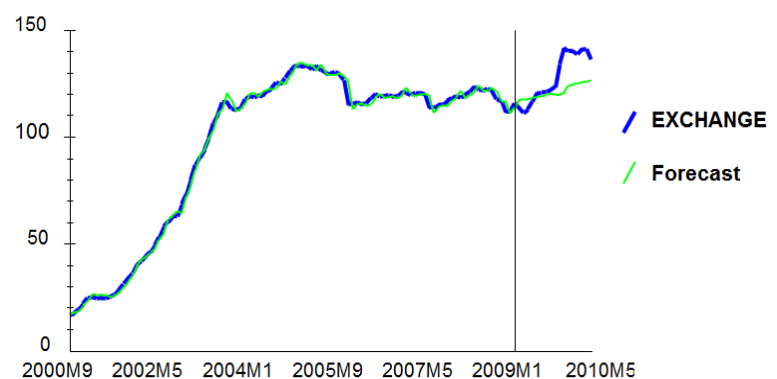

Months 
Figure 1c. Angola Kwanza CUSUM Graph

Angola: Plot of Cumulative Sum of Recursive Residuals

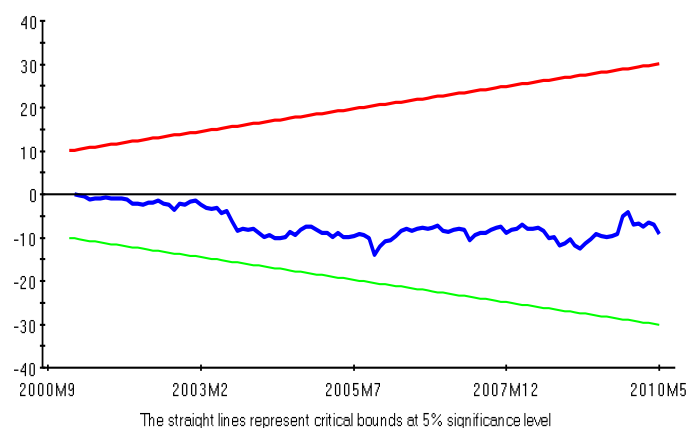

Figure 2a. Botswana Pula Exchange Rates from 1990 to 2010

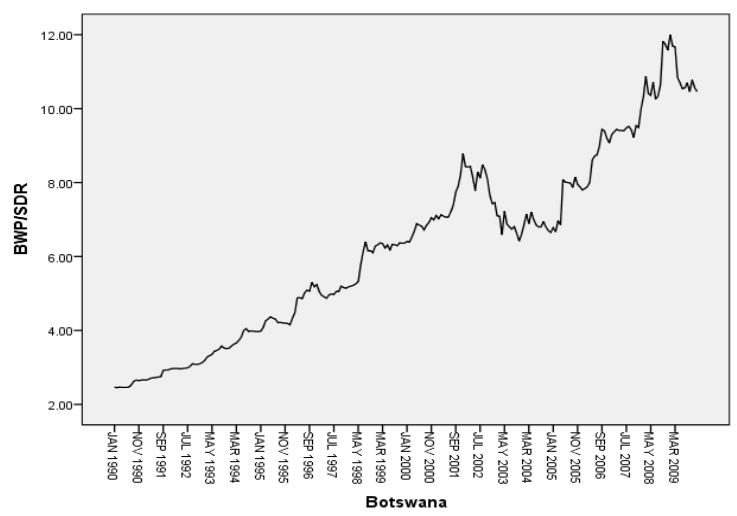

Figure 2c. Botswana Pula CUSUM Graph

Botswana: Plot of Cumulative Sum of Recursive Residuals

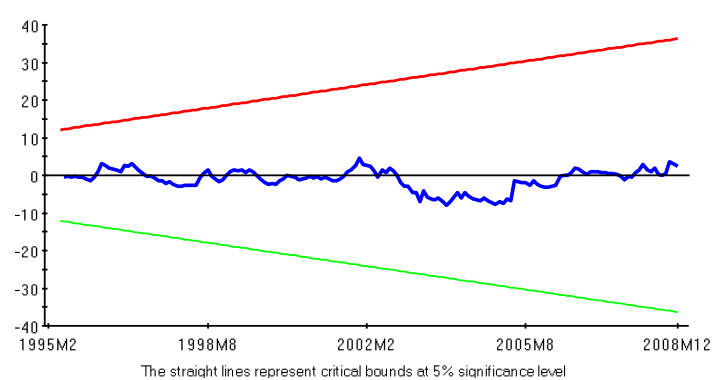

Figure 1d. Angola Kwanza CUSUMSQ Graph

Plot of Cumulative Sum of Squares of Recursive Residuals

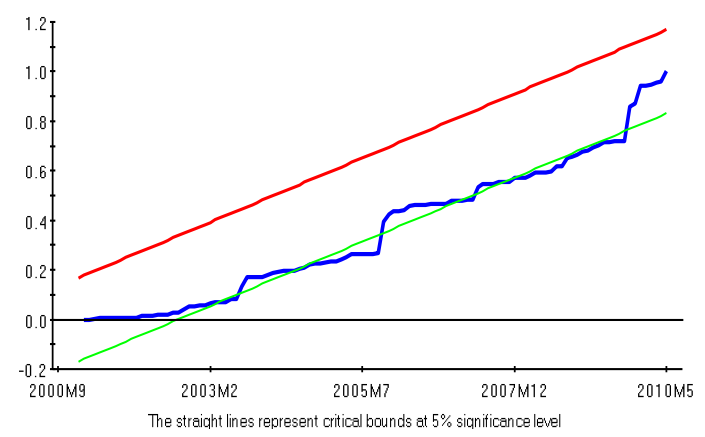

Figure 2b. Botswana Pula Forecasts

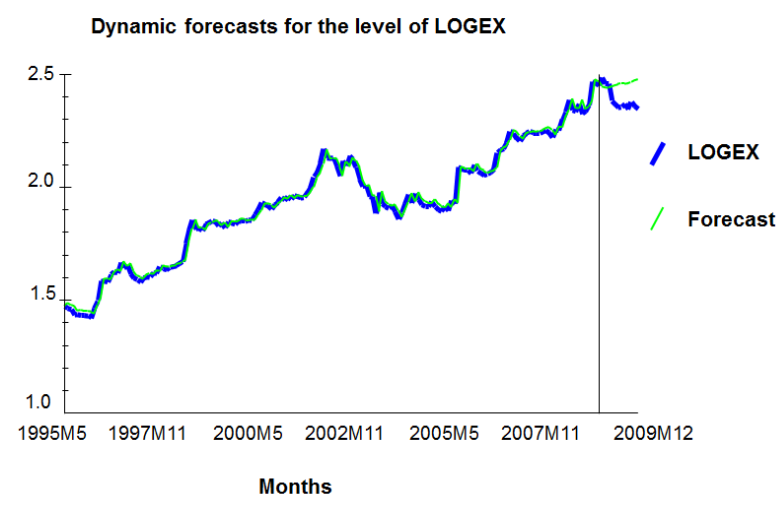

Figure 2d. Botswana Pula CUSUMSQ Graph Botswana: Plot of Cumulative Sum of Squares of Recursive Residuals

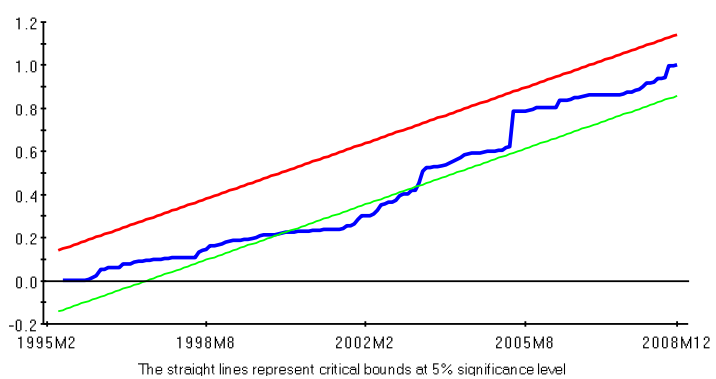


Figure 3a. DRC Franc Exchange Rates from 1990 to 2010

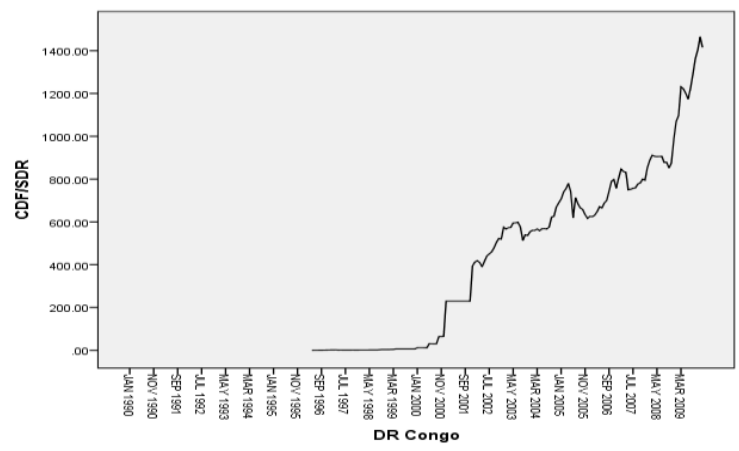

Figure 3c. DRC Franc CUSUM Graph

DR Congo: Plot of Cumulative Sum of Recursive Residuals

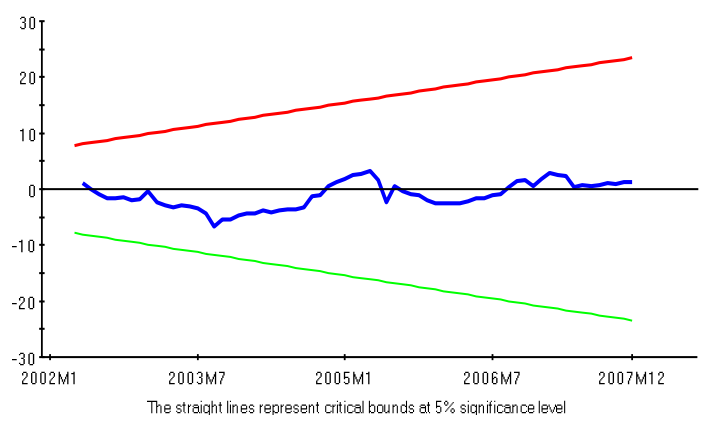

Figure 4a. Madagascar Ariary Exchange Rates from 1990 to 2010

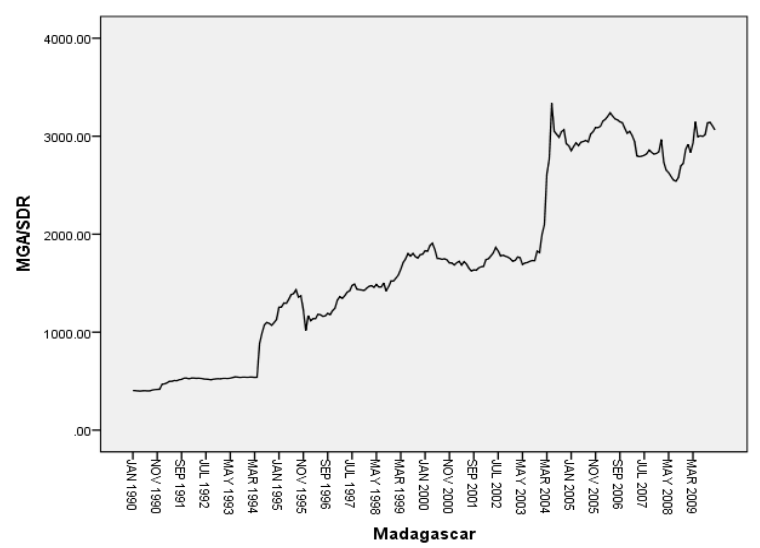

Figure 3b. DRC Franc Forecasts

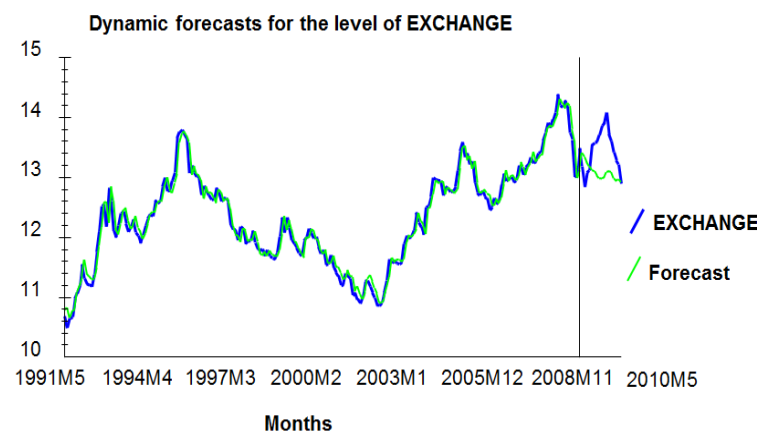

Figure 3d. DRC Franc CUSUMSQ Graph DR Congo: Plot of Cumulative Sum of Squares of Recursive Residuals

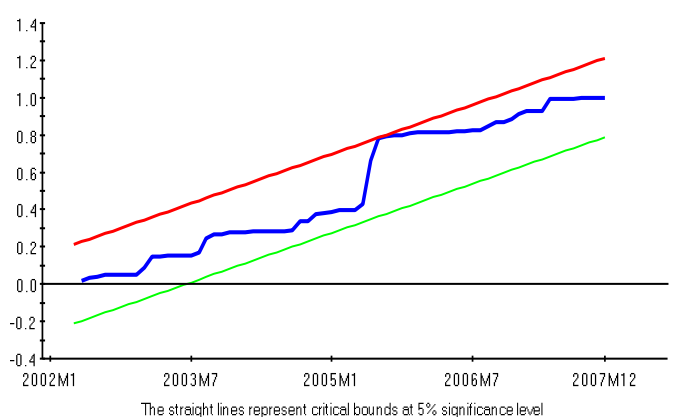

Figure 4b. Madagascar Ariary Forecasts

Dynamic forecasts for the level of LOGEX

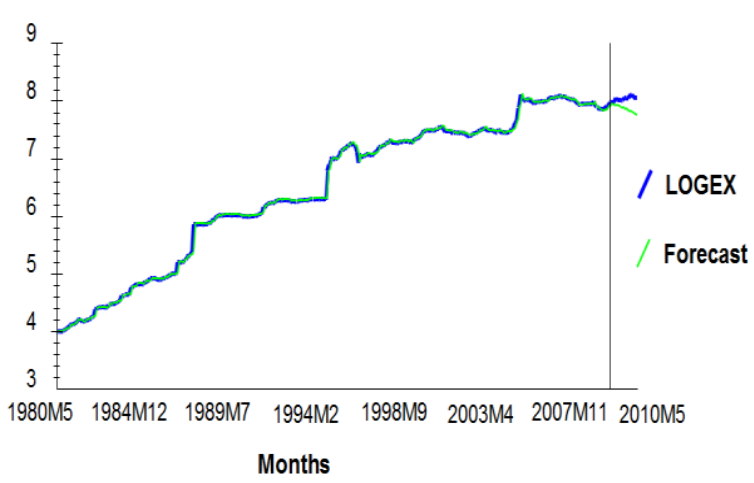


Figure 4c. Madagascar Ariary CUSUM Graph

Madagascar: Plot of Cumulative Sum of Recursive Residuals

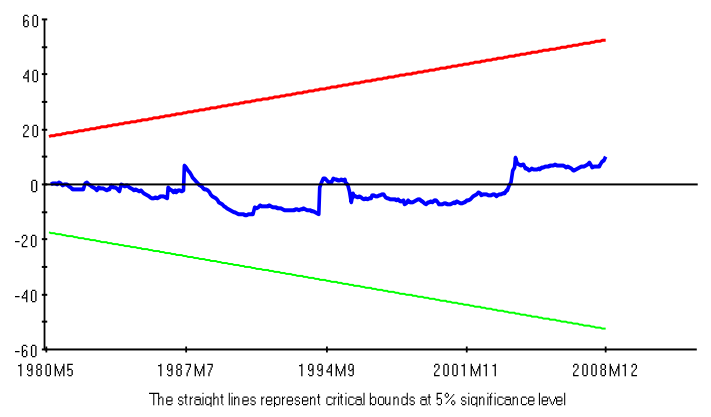

Figure 5a. Malawi Kwacha Exchange Rates from 1990 to 2010

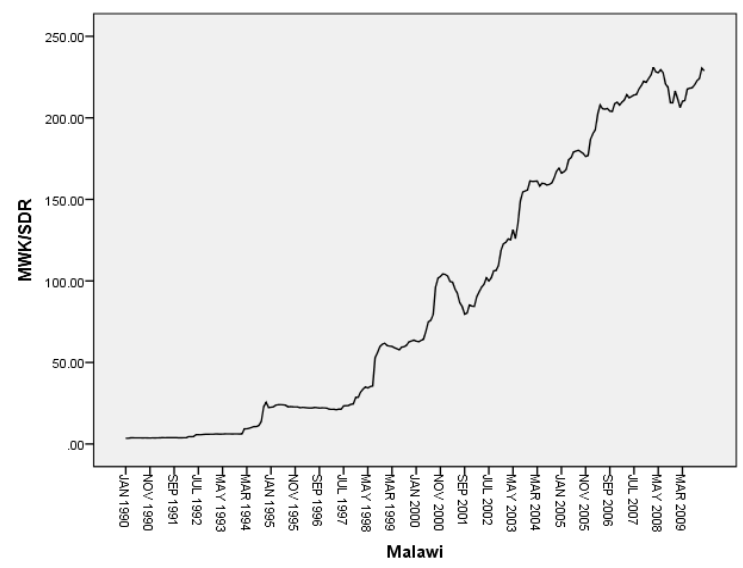

Figure 5c. Malawi Kwacha CUSUM Graph

Malawi: Plot of Cumulative Sum of Recursive Residuals

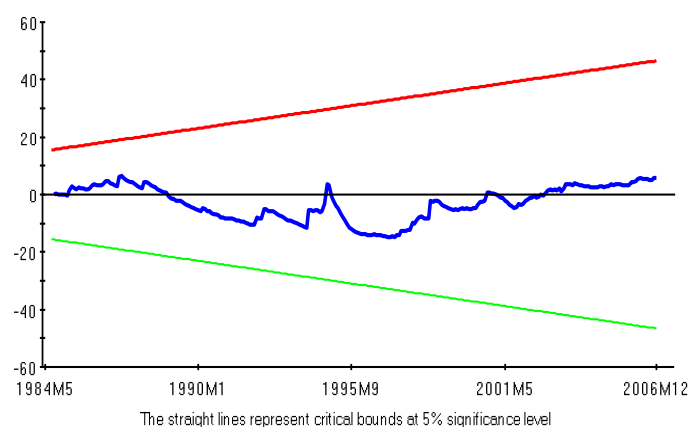

Figure 4d. Madagascar Ariary CUSUMSQ Graph

Plot of Cumulative Sum of Squares of Recursive Residuals

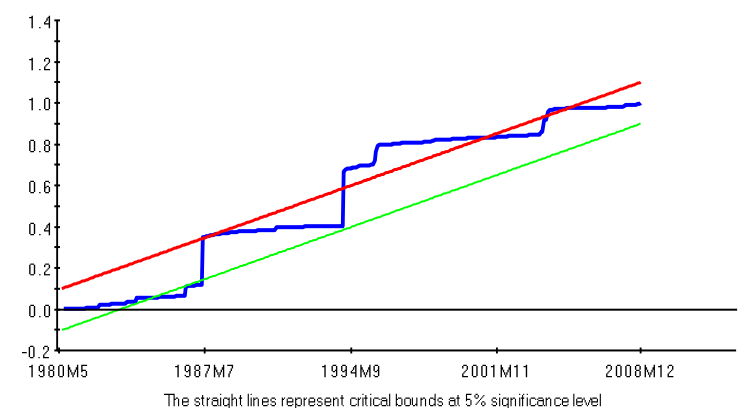

Figure 5b. Malawi Kwacha Forecasts

Dynamic forecasts for the level of LOGEX

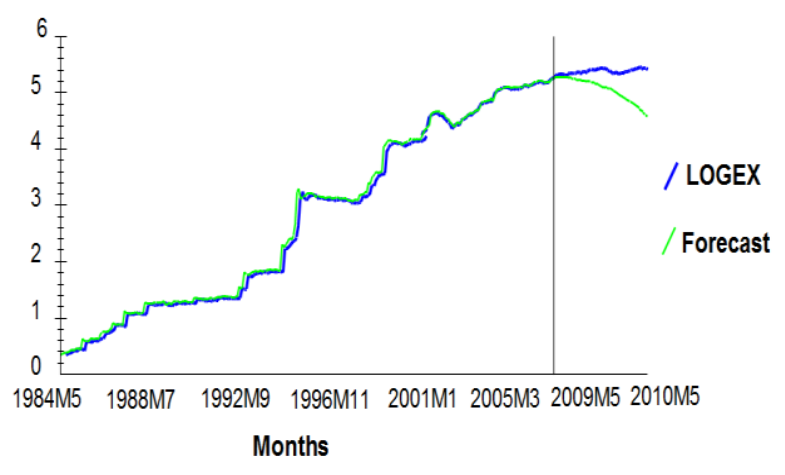

Figure 5d. Malawi Kwacha CUSUMSQ Graph

Malawi: Plot of Cumulative Sum of Squares of Recursive Residuals

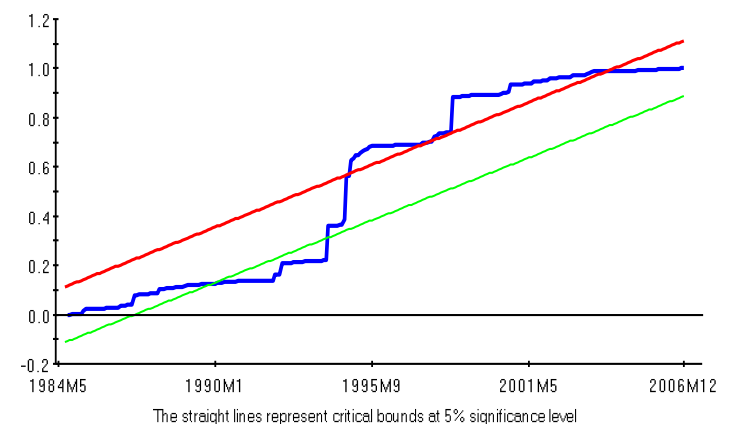


Figure 6a. Mauritius Rupee Exchange Rates from 1990 to 2010

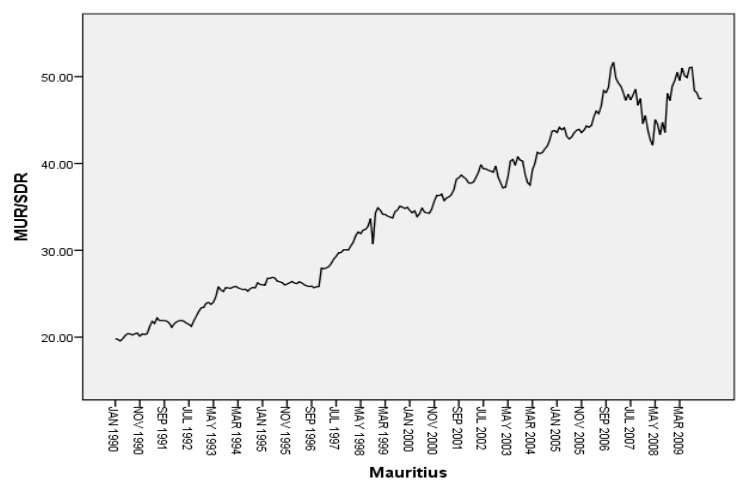

Figure 6c. Mauritius Rupee CUSUM Graph

Mauritius: Plot of Cumulative Sum of Recursive Residuals

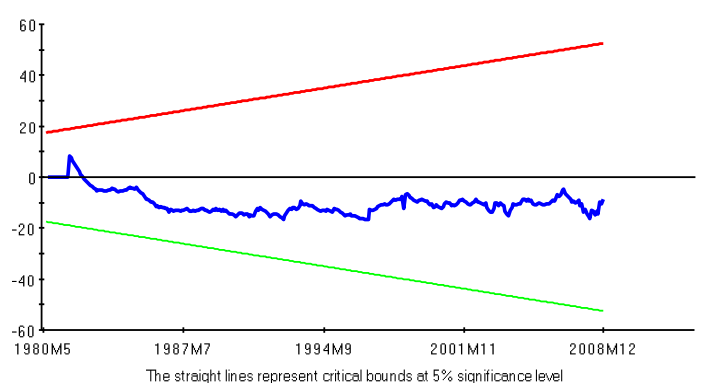

Figure 7a. Mozambique Metical Exchange Rates from 1990 to 2010

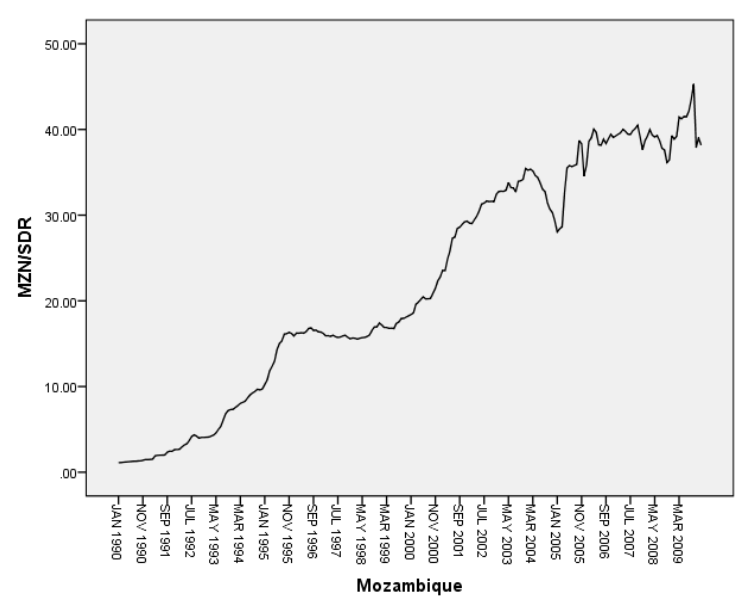

Figure 6b. Mauritius Rupee Forecasts

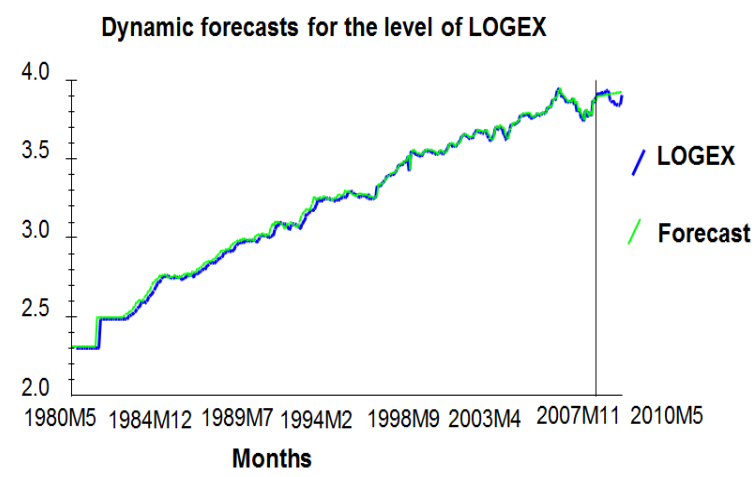

Figure 6d. Mauritius Rupee CUSUMSQ Graph

Mauritius: Plot of Cumulative Sum of Squares of Recursive Residuals

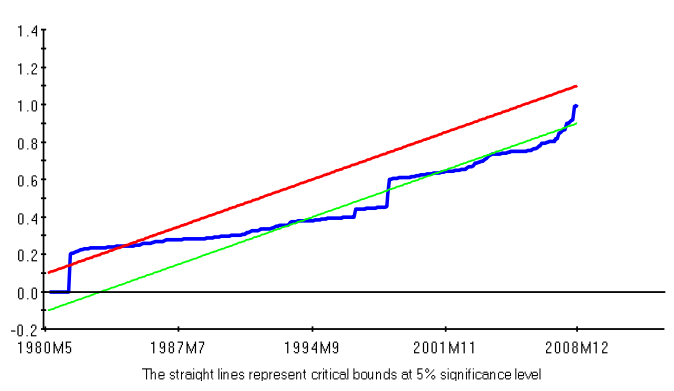

Figure 7b. Mozambique Metical Forecasts

Dynamic forecasts for the level of LOGEX

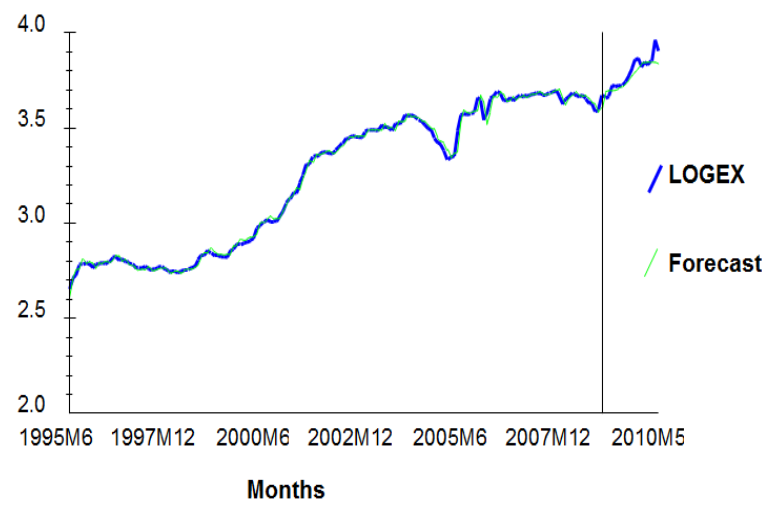


Figure 7c. Mozambique Metical CUSUM Graph

Mozambique: Plot of Cumulative Sum of Recursive Residuals

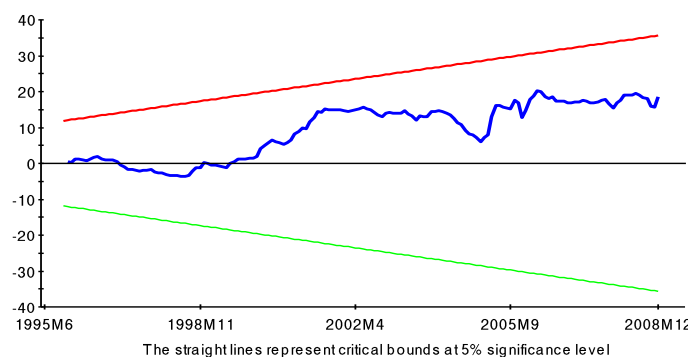

Figure 8a. Seychelles Rupee Exchange Rates from 1990 to 2010

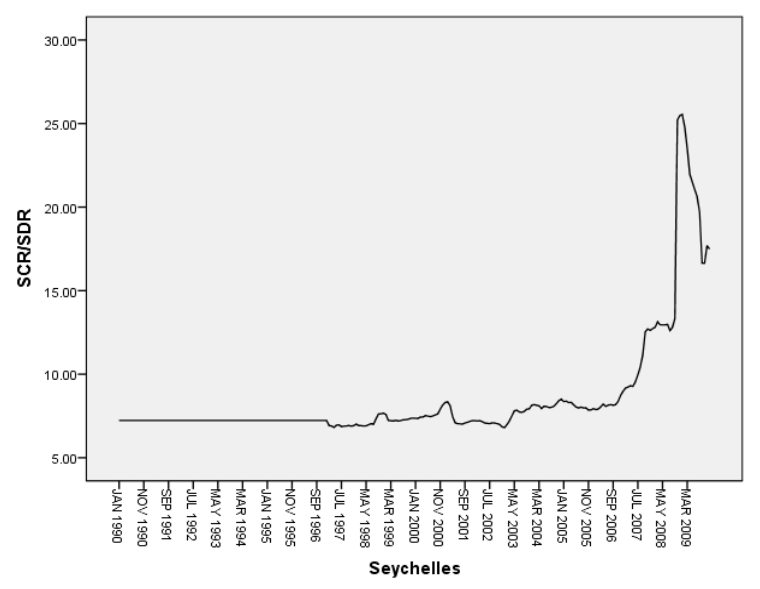

Figure 8c. Seychelles Rupee CUSUM Graph

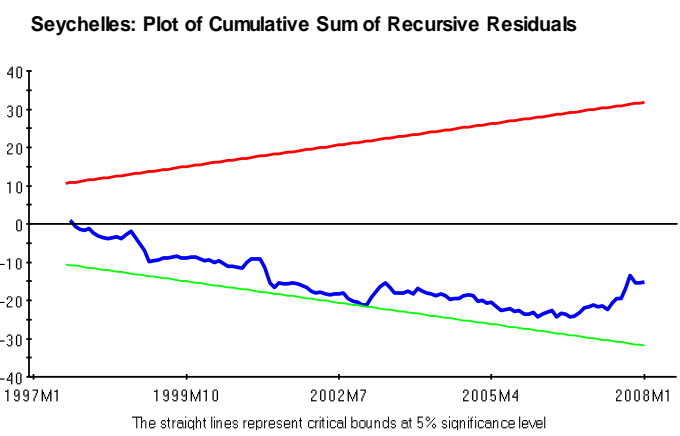

Figure 7d. Mozambique Metical CUSUMSQ Graph

Mozambique: Plot of Cumulative Sum of Squares of Recursive Residuals

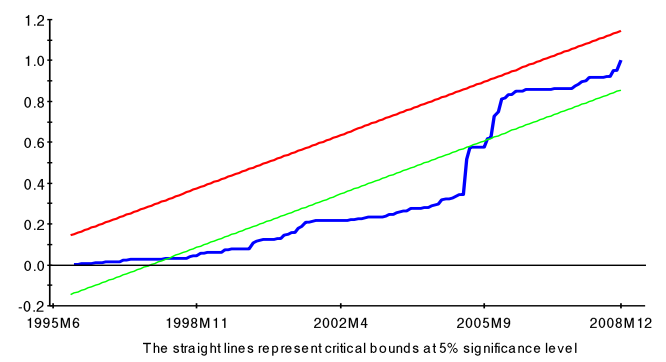

Figure 8b. Seychelles Rupee Forecasts

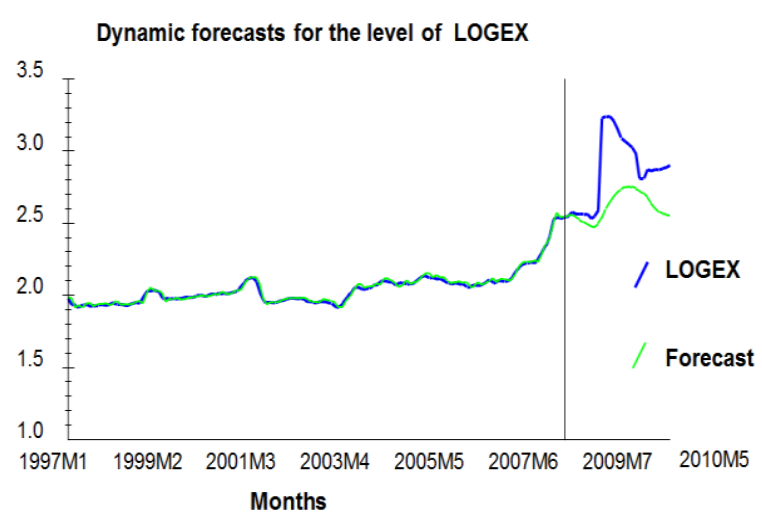

Figure 8d. Seychelles Rupee CUSUMSQ Graph

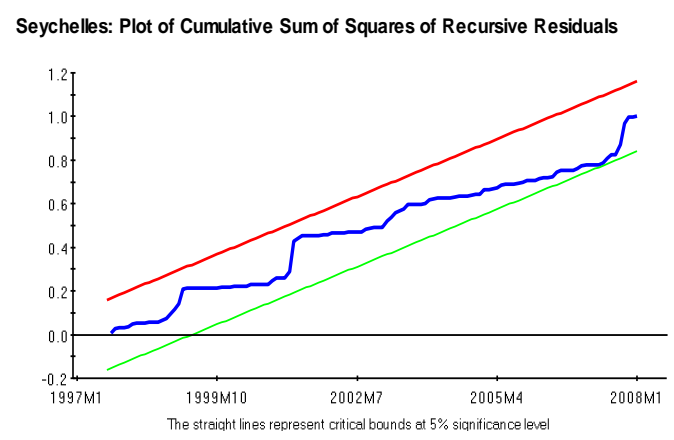


Figure 9a. Tanzania Shilling Exchange Rates from 1990 to 2010

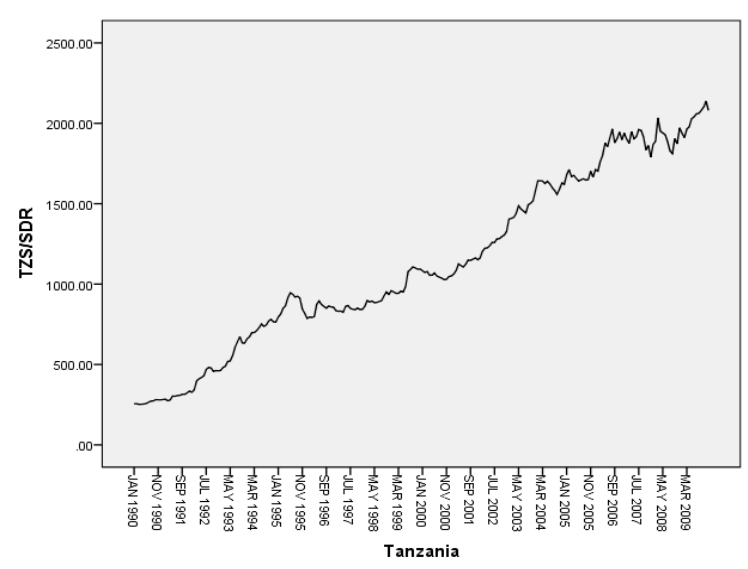

Figure 9c. Tanzania Shilling CUSUM Graph Tanzania: Plot of Cumulative Sum of Recursive Residuals

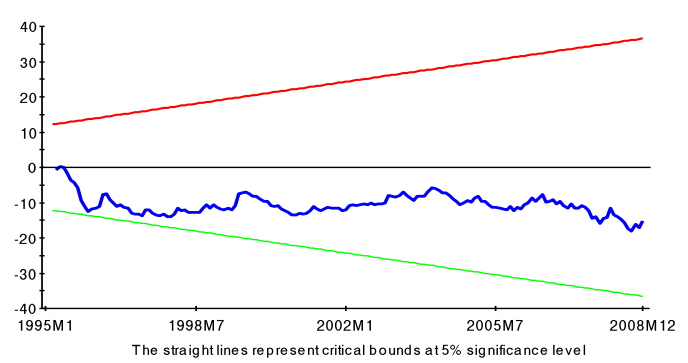

Figure 9b. Tanzania Shilling Forecasts

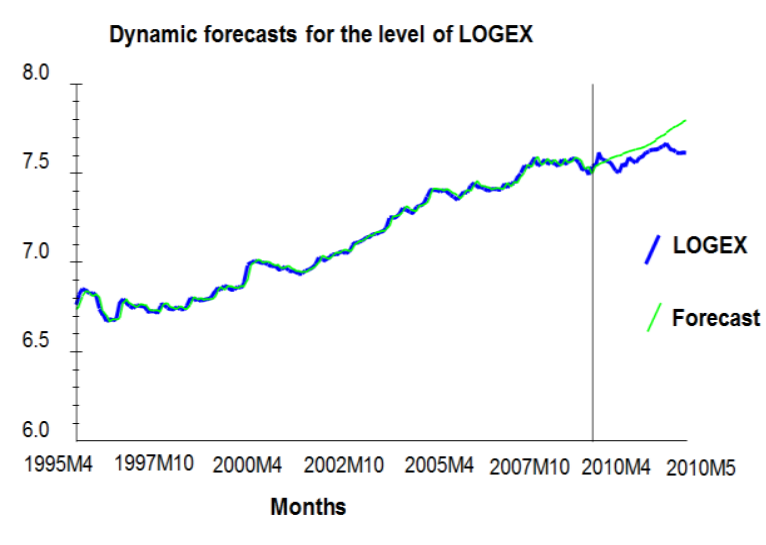

Figure 9d. Tanzania Shilling CUSUMSQ Graph

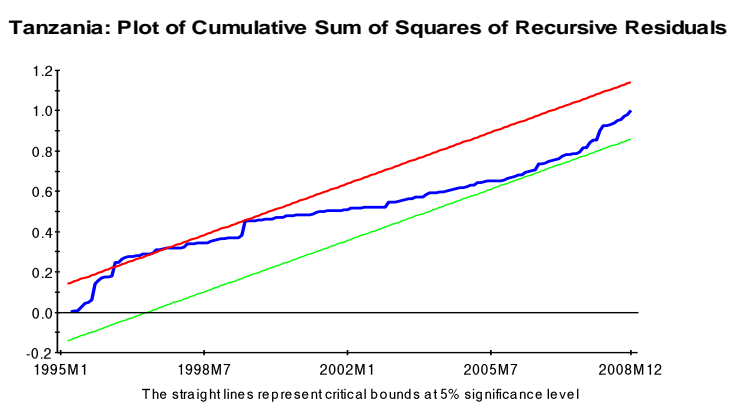

